\title{
Cognitive components, information search processes, and outcomes in a decision making task
}

\author{
Beth A. Stafford \\ West Virginia University
}

Follow this and additional works at: https://researchrepository.wvu.edu/etd

\section{Recommended Citation}

Stafford, Beth A., "Cognitive components, information search processes, and outcomes in a decision making task" (2007). Graduate Theses, Dissertations, and Problem Reports. 2524.

https://researchrepository.wvu.edu/etd/2524

This Thesis is protected by copyright and/or related rights. It has been brought to you by the The Research Repository @ WVU with permission from the rights-holder(s). You are free to use this Thesis in any way that is permitted by the copyright and related rights legislation that applies to your use. For other uses you must obtain permission from the rights-holder(s) directly, unless additional rights are indicated by a Creative Commons license in the record and/ or on the work itself. This Thesis has been accepted for inclusion in WVU Graduate Theses, Dissertations, and Problem Reports collection by an authorized administrator of The Research Repository @ WVU. For more information, please contact researchrepository@mail.wvu.edu. 
Cognitive Components, Information Search Processes, and Outcomes in a Decision Making Task

\title{
Beth A. Stafford
}

Thesis submitted to the Eberly College of Arts and Sciences at West Virginia University in partial fulfillment of the requirements for the degree of

\section{Master of Science}

in

\section{Life-Span Developmental Psychology}

\author{
Julie H. Patrick, Ph.D., Chair \\ Stanley H. Cohen, Ph.D. \\ Amy E. Fisk, Ph.D. \\ Department of Psychology \\ Morgantown, West Virginia \\ 2007
}

Keywords: Cognitive Abilities, Search Strategies, Decision Making 


\begin{abstract}
Cognitive Components, Information Search Processes, and Outcomes in a Decision Making Task

Beth A. Stafford

Data from 49 younger adults with a mean age of 20.8 years old was used to examine the relations among cognitive abilities, information search strategies, and decision quality. Participants completed computerized relocation tasks for hypothetical individuals. A multiple linear regression was used to test the relations among the cognitive components fluid ability (Gf), crystallized ability $(\mathrm{Gc})$, working memory (WM) and decision quality. A multiple linear regression was used to test the relations among the search strategies order of information searched, amount of information searched, search selectivity, and decision quality. A hierarchical regression was used to test the relations among cognitive abilities and the search strategies. A novel affective component was also added to the decision task. Neither of the three cognitive variables, nor the three search strategy variables significantly accounted for decision quality. However, the amount of affective information viewed related to higher quality decisions. Individuals who viewed the affective information were more likely to make good decisions. Results extend prior decision-making research with the addition of the affective information. Future researchers may be able to develop more accurate models of decision making based on this ecologically valid affective information.
\end{abstract}




\section{Dedication}

I would like to dedicate this research project to my mother and cherished friend, Paula Stafford, who has made my entire academic career possible. You continuously assured me that I could do anything in this world that I want, and that this was no different. Thank you for supporting me and giving me the courage and drive to continue when I wanted to give up. 


\section{Acknowledgments}

I would first like to thank my advisor, Dr. Julie H. Patrick, for supporting me and providing her ideas, knowledge and guidance for completing this project. I would also like to thank Dr. JoNell Strough for her continued guidance and advice during the process. Thank you to my committee, Dr. Stanley Cohen, and Dr. Amy Fiske, for your advice and helpful suggestions for completing this project.

I would like to thank my research assistant Trista Hoosier, who helped enter and code the data. Thank you for your time and dedication, and your optimistic attitude during the process.

I would also like to thank all of my amazing friends for their continued support and encouragement. Thanks especially to Kimberly Haines, Michelle Guy, Andrea Rauch, James Diller, Laura Cook, and Jonah Toler for their special attention and guidance.

Finally, I would like to thank my family for their constant love and support. Thanks especially to my parents, Jeff and Paula Stafford, my grandmother Thelma Ryan, and my sister Angela Stafford, for their continuous guidance and encouragement.

Thank you to everyone for having faith in me. 


\section{Table of Contents}

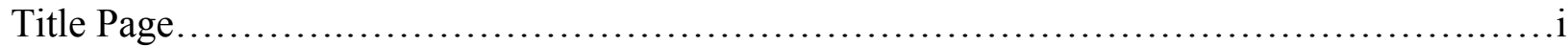

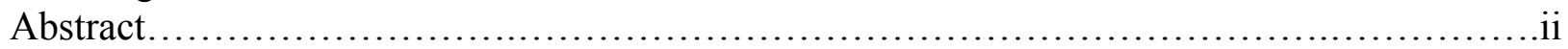

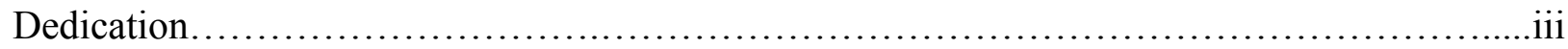

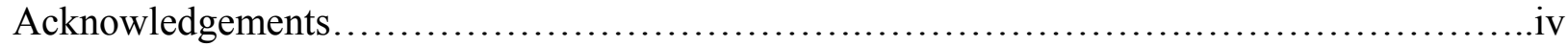

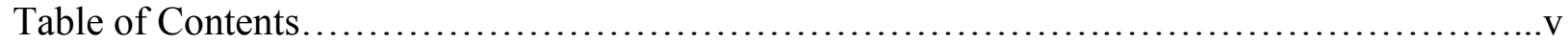

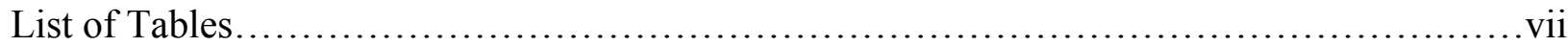

Chapter 1: Problem Statement..........................................................

Cognitive Abilities...........................................................

Problem Solving and Decision Making............................................

Relocation Decisions ............................................................

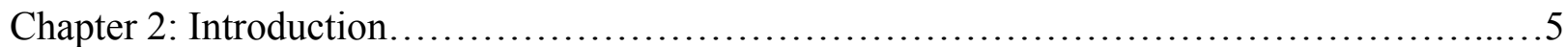

Psychometric Intelligence....................................................

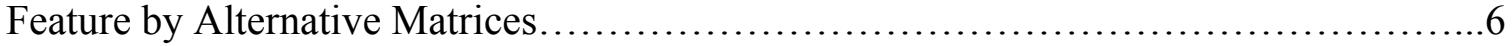

Theoretical Framework........................................................ 11

Rationale.................................................................. 12

Research Questions and Hypotheses .............................................. 13

Chapter 3: Method............................................................... 15

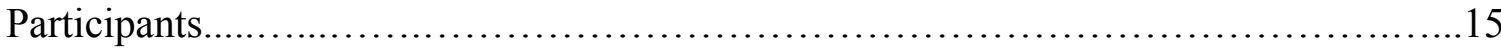

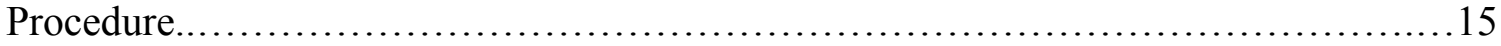

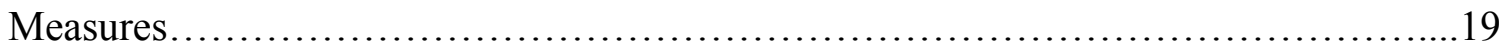

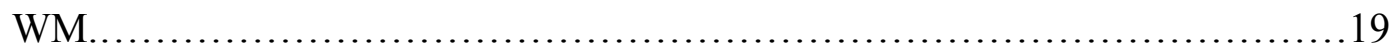

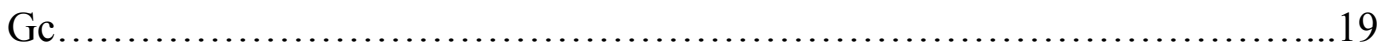

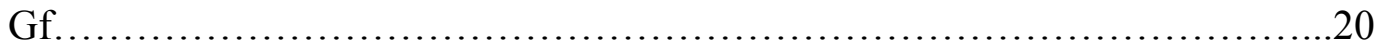

Amount of Information Searched..........................................20

Order of Information Searched...........................................21

Search Selectivity...................................................22

Decision Quality.................................................. 22

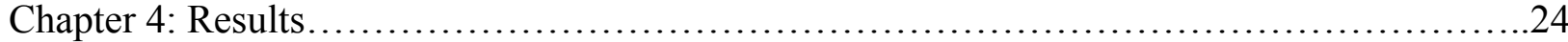

Descriptive Results....................................................... 24

Research Questions and Hypotheses........................................25

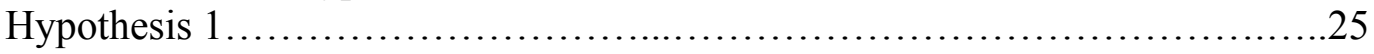

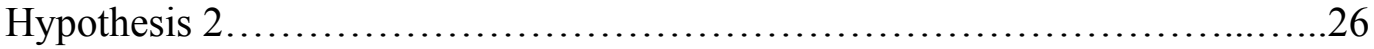

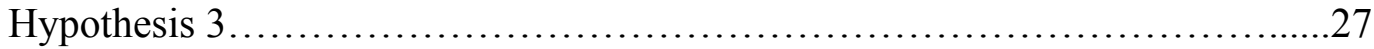

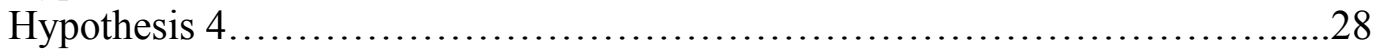

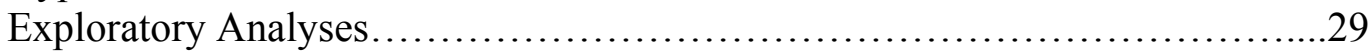

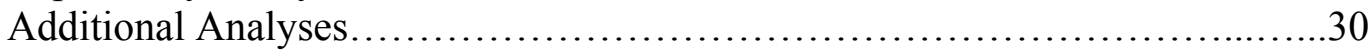

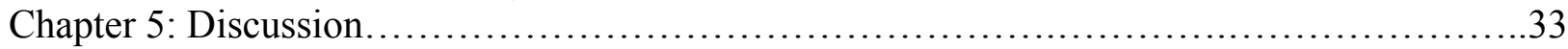

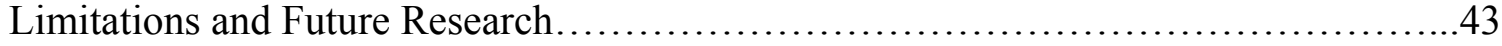

References...........................................................................

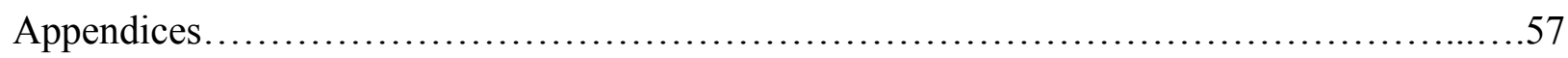

Appendix A: Decision Vignettes............................................57

Appendix B: Decision Matrices............................................... 58

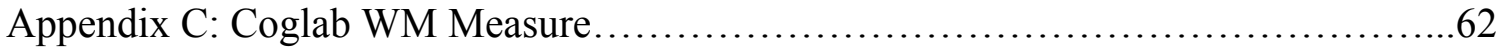


Appendix D: Survey Materials.................................................63

Appendix E: Consent Form..................................................... 70 


\section{List of Tables}

Table 1: $\quad$ Descriptive Statistics of Variables.......................................49

Table 2: $\quad$ Pearson Correlations between Variables.....................................50

Table 3: $\quad$ Summary of Linear Regression Analyses Predicting Decision Quality...........................................................51

Table 4: $\quad$ Summary of Linear Regression Analyses Predicting Decision Quality..............................................................52

Table 5: $\quad$ Summary of Hierarchical Regression Analyses Predicting Decision Quality....................................................53

Table 6: $\quad$ Summary of Exploratory Linear Regression Analyses Predicting Decision Quality.......................................................5 54

Table 7: $\quad$ Summary of Post-hoc Linear Regression Analyses Predicting Decision Quality....................................................... 55

Table 8: $\quad$ Pearson Correlations between the Cognitive and Search Strategy Variables................................................................56 


\section{Chapter I}

\section{Introduction}

\section{Cognitive Abilities}

Significant research has examined the role of intelligence in the performance of various tasks (Neisser et al., 1996). When considering intelligence, most researchers assess crystallized and fluid abilities, as described in Horn's psychometric approach to intelligence. Horn's twofactor theory of psychometric intelligence describes crystallized intelligence (Gc) as information that is learned and accumulated over the years, such as content knowledge and facts. Fluid intelligence (Gf) is performance-based and includes the ability to solve problems with diverse applications of knowledge (Horn \& Cattell, 1966). Horn and Cattell (1966) suggest that Gf can be measured by reasoning, concept formation, perception, and tasks involving abstraction. Gc can be measured primarily using verbal comprehension tasks (Horn \& Cattell, 1966). Along with Gf and Gc, working memory (WM) is also an important component of intelligence. Working memory involves the simultaneous storage and manipulation of information (Baddeley, 1998). Extending Horn's original two-factor approach to intelligence to incorporate WM, Ackerman (2000) suggests a three-factor approach to intelligence, in which Gf, Gc, and WM are considered to be intermediate factors, supported by a host of other basic cognitive abilities.

Including the addition of WM as third factor, most research examining intelligence and behavior relies on these psychometric indices because they relate to everyday behavior (Ackerman, 2000; Ackerman \& Rolfus, 1999). Specifically, cognitive abilities predict problemsolving and decision-making outcomes (Diehl, Willis, \& Schaie, 1995). 
Everyday Problem Solving and Decision Making

Previous research has typically examined problem-solving and decision-making separately due to the dependent variable measured in each task (Thorton \& Dumke, 2005). Everyday problem solving focuses on the number of effective solutions one can generate to solve a problem, whereas decision-making research deals with speed and the amount of information required in making a decision (Thorton \& Dumke, 2005). In a recent meta-analysis, Thorton \& Dumke (2005) investigated the existence of age differences in the problem-solving and decisionmaking literatures. Studies from both literatures were included because recent decision-making research has looked at both decision-making effectiveness and quality, and the term everyday problem solving/decision-making effectiveness (EPSE) was used. Data from 28 studies were included with a total of 4,482 participants. Thorton and Dumke examined age groupings of “older" (60+), "middle-aged” (40-59), and “young” (18-39) adults. Results indicated reliable age differences, with EPSE being highest among young and middle-aged adults. Further, results indicated that younger adults performed equally as well to middle-aged adults suggesting that EPSE does not peak in middle-age. Situations focused on interpersonal problems however showed smaller age differences. This finding is consistent with previous research suggesting that interpersonal problems may be more emotionally salient in older adulthood (Blanchard-Fields et al., 1995). Overall, results supported two hypotheses: 1) That experience drives differences in EPSE, and 2) That EPSE is reduced in advanced age (Thorton \& Dumke, 2005).

\section{Relocation Decisions}

Researchers often use hypothetical vignettes to analyze what factors contribute to problem solving and decision making in various real-world domains. Participants are presented with a hypothetical scenario, and then must indicate their solution for the task (Blanchard-Fields, 
Jahnke, \& Camp, 1995; Johnson, 1990; Patrick, 1995; Patrick, Spencer, \& Johnson, 2003;

Patrick \& Strough, 2004; Stafford, 2004). Patrick and Strough (2004) however, point out the benefits of merging the fields of everyday problem-solving and decision-making research. Their study asked older adults to complete a hypothetical relocation vignette, and also whether they were actually considering relocating. Thus, problem-solving strategies and actual relocation intentions were assessed in this study. Results showed that the actual decision on the vignettes related to strategies used, and also to real world intentions (Patrick \& Strough, 2004). The benefit of this study is the ecological validity it possesses. However, few studies have been completed that show this link between lab behavior and real world intentions (Patrick \& Strough, 2004).

In the decision-making and problem-solving literatures, relatively few studies look at realistic decisions adults may have to make during their lives (Patrick \& Strough, 2004). Patrick and Strough (2004) also point out that more research needs to be directed to linking lab-based performance to performance in the real world. The proposed study may help begin the examination of this link by using a highly salient decision-making scenario and examining how participants make their decisions. The features used in previous studies examining relocation decisions have included details such as monthly cost, size, location, non-medical and medical services, social activities and security issues. These features are derived from previous work completed in relocation decision-making research (Patrick et al., 2003; Stafford, 2004). Previous studies have shown that each feature surfaces as an important component when adjusting to a new environment (Everard et al., 1994; Gilderbloom \& Mullins, 1995). The proposed study however, replicated and extended previous research by adding an affective component to the information decision makers could choose from when picking a relocation option. 
Blanchard-Fields, Jahnke, and Camp (1995) examined the role of emotional salience and how it affected age differences in problem-solving style. This study had 287 participants: 142 females and 115 males. Four age ranges were included in the study: 1) Adolescents (14-17), 2) Young adults (25-35), 3) Middle-aged adults (45-55), and 4) Older adults (65-75). Participants responded to 15 problem-solving vignettes and rated them according to the amount of emotion each induced. The vignettes were then compiled into three categories: low emotional salience, medium emotional salience, and high emotional salience. Participants were also asked to generate their own solutions to the scenarios. Results show that emotional salience affected the problem solving style. As emotional salience increased, problem-focused strategies decreased and emotion-focused strategies increased. There were no age differences in the low emotionalsalience problems, but older adults used more emotion-regulating strategies in both the middle and highly emotional salience problems. This study shows that problem-solving strategies differ depending on the emotional salience of the problem and the age of the problem solver. Research involving real-world problems suggests that older adults implement different problem solving strategies than younger adults in problems including an emotional component (Blanchard-Fields et al., 1995). Similarly, an emotional component was added to the current study to determine if there are differences in the type of information that is viewed during a relocation task. 


\section{Chapter II}

\section{Literature Review}

\section{Psychometric Intelligence}

Ackerman and Rolfus (1999) examined indices of intelligence in a sample of middleaged adults. One hundred and thirty five middle-aged adults participated in the study. ( $N=42$ men and 93 women; Mean age $=40.2$ years). Participants completed tests that included topics such as history, applied and social science, and technical topics. The goals of the study were to examine how knowledge predicts performance on the twenty tests, and to examine knowledge in older adulthood (Ackerman \& Rolfus, 1999). Results from this study show that abilities are important predictors of knowledge beyond education. Gc, Gf, personality and interests were found to predict individual differences in performance. The middle-aged adults outperformed the young adults on all of the test subjects except for chemistry. However, younger adults performed better on the numerical and spatial measures (Ackerman \& Rolfus, 1999). The results are of interest to the current study because the cognitive indices Gf and Gc were related to the outcomes of the knowledge measures (Ackerman \& Rolfus, 1999).

Ackerman (2000) investigated age differences in intelligence across multiple domains. Two hundred and twenty eight adults participated in this study, ranging in age from 21-62 years old, with a mean age of 34.2. Eighteen domains were chosen from previous work by Ackerman \& Rolfus (1999) in order to assess participants' knowledge. These real-world tasks were used to determine how middle-aged adults would perform compared to younger adults. Concordant with previous research (Schaie, 1996), results showed that Gf and age are negatively correlated, and that Gc and age are positively correlated. In this study however, age differences were nonexistent, indicating that middle-aged and younger adults performed at about the same level. 
Ackerman (2000) suggested that these results are of importance because intelligence tests that measure Gf and Gc were able to predict individual differences in real-world performance (Ackerman, 2000). It is also evident from these results that cognitive components such as Gf and Gc can be linked to outcomes of various tasks (Ackerman, 2000).

Diehl, Willis, \& Schaie (1995) also linked cognitive components to outcomes. In their study concerning everyday problem solving in older adults, Gf and Gc were linked to problem solving outcomes. Sixty-two older adults with a mean age of 76.4 years participated in this study. Participants' problem-solving abilities in food preparation, telephone use, and medication intake were assessed using the Observed Tasks of Daily Living (OTDL) measure. Results suggested that cognitive abilities had direct and indirect influences on performance on the OTDL. In particular, higher Gf and Gc were associated with higher OTDL scores. Further, Gf showed the strongest association across all three domains of daily living and was the most salient predictor of problem solving performance (Deihl et al., 1995). These results are of interest to the current study because higher Gf and Gc are linked to better problem solving performance (Diehl et al., 1995).

Feature by Alternative Matrices

Payne (1976) used feature by alternative matrices in order to examine the search strategies of individuals while making housing decision for themselves. Data was collected from six younger adults. Participants were presented with information boards that contained information about various apartments. The information boards varied in size by the number of alternatives and features that were available for each alternative. The search strategies examined were the amount of information searched and pattern of search. A compensatory search strategy involved looking at numerous features for one apartment setting, while an a noncompensatory 
search involved viewing one feature for all of the apartment options, such as checking the price for each available option. Results showed that the amount of information viewed declined as the number of alternatives and features per alternative increased. Further, the search strategies changed as the amount of information in the matrices increased. When there were only two alternatives available, participants used a compensatory strategy by viewing all of the information available for each alternative, however when there were six or twelve alternatives available, participants utilized a noncompensatory strategy by viewing different amounts of the features based on their preferences. Compensatory strategies occur when decision makers view a constant amount of information for each alternative, while noncompensatory strategies occur when decision makers initially eliminate some of the alternatives based on viewing only some of the features concerning each alternative (Payne, 1976). Participants reduced the amount of information they viewed by using noncompensatory strategies as a cognitive short cut. These results suggest that search strategies change based on the difficulty of the decision task (Payne, 1976). Like Payne (1976), the current study examined decision making via housing options with a younger adult sample.

Similarly, Olshavsky (1979) used feature by alternative matrices to investigate search strategies on two tasks, choosing a condominium apartment and a stereo receiver. Participants were presented with information via index cards. Results were similar to those of Payne (1976) in that the amount of information viewed decreased as the amount of information in the matrix increased. Similarly, the time spent viewing information decreased as the amount of information in the matrix increased. Search strategies also differed based on the amount of information that was presented. When there were only three alternatives available, participants tended to use a compensatory search strategy, however, when there were twelve alternatives available, 
participants utilized a noncompensatory strategy. Further, participants would initially view only some information regarding the features of alternatives, thus producing a smaller list of alternatives that they could chose from. After they initially eliminated some of the choices, participants then switched back to a compensatory search strategy for the remaining options, indicating a multistage strategy (Olshavsky, 1979). These results replicated and extended the work of Payne (1976) by suggesting that decision makers may first implement a noncompensatory strategy as a shortcut in reducing the available options, and then utilize a compensatory strategy when choosing between more personally relevant items. Consistent with Payne (1976), these results suggest that search strategies change based on task difficulty (Olshavsky, 1979). Feature-based order of information searched was examined in the current study because it is indicative of a noncompensatory search strategy (Olshavsky, 1979; Payne, 1976). Eight housing alternatives were included in the current study, so it is more likely that participants would utilize a noncompensatory search strategy due to efforts in reducing the cognitive demand of the task.

Using a standard decision matrix, Johnson (1990) linked cognitive capacity to search strategies, focusing on dependent variables such as the number of pieces of information viewed, and the order in which information was viewed. Data from 36 college students (Mean age $=$ 18.7), and 36 older adults (Mean age $=65.7$ ) were collected. Participants were asked to choose a car for themselves. The automobile alternatives differed on several features, including cost, size, style, resale value, and interior room. The purpose of the study was to determine if older adults used different strategies or required more time than younger adults when faced with a real-life decision. Age differences did not emerge in terms of total time on task. However, younger adults looked at more pieces of information and were more likely to review information. Thus, 
compared with older adults, younger adults viewed each piece of information for shorter periods of time. In addition to amount of information viewed, age differences also emerged in search strategy (Johnson, 1990). Younger adults tended to implement compensatory strategies, which typically use more of the available information. In contrast, older adults tended to use noncompensatory search strategies, which reduce the amount of processing involved in a task and serve as a heuristic (Payne, 1976). Results of Johnson (1990) are relevant to the current study because they link cognitive capacity to search strategies. However, Johnson (1990) did not assess decision quality. Recently, researchers have begun using experts in order to determine which of the decision outcomes and features are most appropriate (Patrick, Spencer, \& Johnson, 2003, Stafford, 2004). This allows researchers to determine whether participants are making correct choices, and also to determine whether they are looking at the important information for the decision task. Search selectivity refers to the amount of relevant information viewed in a decision scenario (Patrick et al., 2003).

Patrick et al. (2003) examined search processes and decision quality in a real world consumer task. Participants included 176 adults ranging in age from $18-93$ years old. The consumer task implemented in this study was an automobile choice for either an older couple who entertained clients, or a younger college-age student who commuted daily to work and school (Patrick et al., 2003). Participants read vignettes and then made a hypothetical automobile choice for both the older couple and the younger college student. Therefore, decision quality and search selectivity were assessed because participants chose a car for a hypothetical target. Results showed that search processes were associated with decision quality, in that; lower amounts of information searched and higher selectivity were both associated with better decisions (Patrick, 1995). Further, WM indirectly influenced decision quality through its 
association with search selectivity, and also directly influenced decision quality (Patrick et al., 2003). The results of Patrick et al., (2003) are relevant to the current study because they link search processes and WM to decision outcomes. Search selectivity was examined in the current study because previous research has found that higher selectivity is associated with better decision quality (Patrick, 1995). Amount of information searched was also examined in the current study because previous research has indicated that it is related to decision quality. Specifically, Johnson (1990) found that younger adults viewed more pieces of information when making a decision, while Patrick et al. (2003) found that individuals who looked at less information were more likely to make better decisions.

Similarly, Stafford (2004) investigated Gf, Gc, \& WM in relation to decision quality and search selectivity. Participants read vignettes and then made relocation decisions for hypothetical individuals. The hypothetical targets differed in terms of their social and health care needs. In accord with previous research (Johnson, 1990; Patrick, 1995, Patrick et al., 2003) information was presented via computerized alternative by feature matrices. Results from this study indicated that WM, Gc, and Gf predicted decision quality and selectivity in older adults. The cognitive abilities Gf, Gc, and WM accounted for $76 \%$ of selectivity, meaning that individuals higher in Gf, Gc, and WM were more likely to look at more relevant pieces of information during a decision-making task. Further, results showed that WM surfaced as the only cognitive component to uniquely predict decision quality, suggesting that individuals with larger working memories were more likely to make correct decisions. Stafford's study is relevant to the current study because the results integrate cognitive abilities, the search processes involved with decision-making and problem solving, and actual decision-making outcomes. By linking cognitive abilities and information search processes with decision-making outcomes, researchers 
may better understand the components of decision making and problem solving. Like Stafford (2004), the current study will assess the cognitive abilities Gf, Gc, and WM and their relation to decision-making outcomes. Gf was assessed using Raven's advanced progressive matrices, Gc was assessed using Thurstone's verbal meaning measure, and WM was assessed using a memory span from the online Wadsworth cognitive laboratory.

\section{Theoretical Framework}

The following decision making model is included in order to show the hypothesized relationships between the cognitive variables, search strategies, and decision-making outcomes. The model is derived from Patrick et al. (2003). A path analysis was used to test the pathways among the constructs. The solid lines indicate significant relationships. The dotted lines indicate relationships that were not significant in Patrick et al. (2003). The solid bold line indicates the direct relationship between WM and decision quality. WM was the only cognitive variable to significantly account for decision quality. WM also indirectly influenced decision quality through selectivity. Individuals with larger WM's were more likely to look at important information, thus they were more likely to make higher quality decisions. Less information searched and higher selectivity were associated with better decision quality.

Age indirectly influenced decision quality through the associations between order of information searched, amount of information searched, and selectivity. Age and order of information searched were negatively related, and age did not predict decision quality. Age and the amount of information were negatively related. Younger adults viewed more total information, while the older adults viewed less information, most likely because of restraints on cognitive capacity. Finally, age and selectivity were negatively related, indicating that younger adults looked at more selective information, while older adults viewed less selective information. 


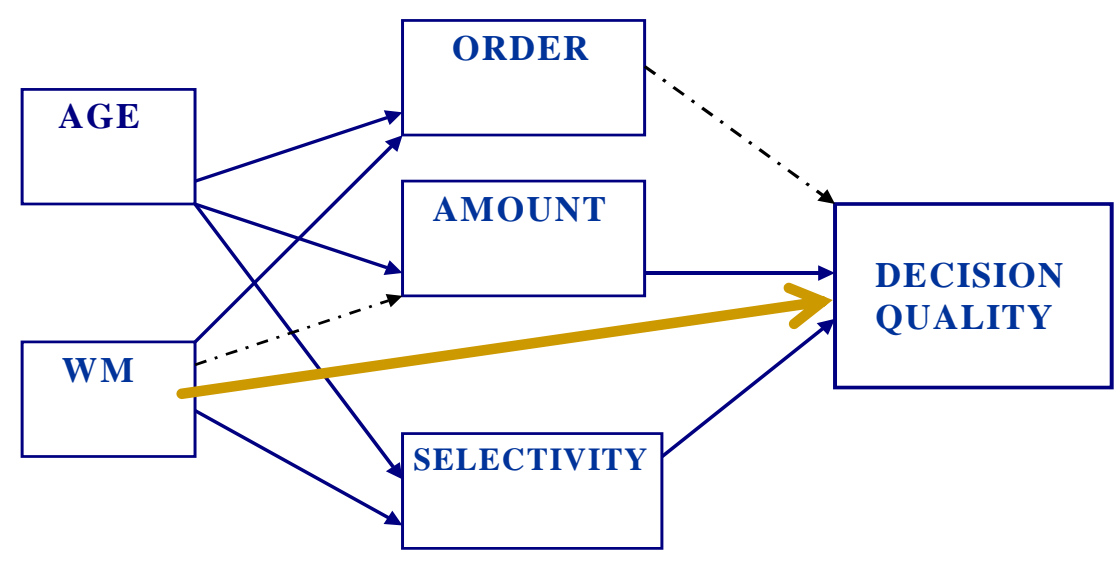

\section{Rationale}

Previous research has shown that Gf, Gc, and WM each influence the outcome of decision making and real-world behaviors (Diehl et al., 1995; Johnson, 1990; Patrick, 1995; Patrick et al., 2003; Stafford, 2004). Task performance variables, namely selectivity and amount of information searched, also influence the quality of decision-making (Patrick et al., 2003; Stafford 2004). However, little research exists in the current literature examining cognitive abilities, processes involved in decision making, and actual decision outcomes simultaneously. Similarly, relatively few studies exist that have incorporated affective information along with cognitive and task performance variables (Blanchard-Fields, 1995; Sonntag, 2006). The goal of the current study is to concurrently examine and integrate cognitive abilities, task performance processes, and relocation decisions. Gender was evaluated in the current study because little research exists that has examined whether there are any gender differences regarding decisionmaking outcomes. The current study also sought to examine the emotional information viewed in a relocations decision. The novel affective information is of interest because previous decisionmaking research utilizing alternative by feature matrices has focused on quantitative information such as rent, size, and cost, medical services, non-medical services, safety information, and 
location (Patrick et al., 2003; Stafford, 2004). The current study will address the above issues and is guided by the following research question and hypotheses:

\section{Research Questions and Hypotheses}

\section{Research Question 1.}

How were cognitive variables related to decision making outcomes in a relocation task?

Hypothesis 1. Based on previous literature (Patrick et al., 2003; Stafford, 2004), cognitive abilities were expected to be associated with decision quality. Specifically, higher Gf, Gc, and WM were hypothesized to be associated with better quality decisions.

\section{Research Question 2.}

How were the task performance variables related to decision making outcomes in a relocation task?

Hypothesis 2. Based on Patrick et al. (2003) and Stafford (2004), task performance variables were hypothesized to influence decision quality. Specifically: 1.) Increased search selectivity would be associated with higher quality decisions (Patrick et al., 2003; Stafford, 2004), 2.) Order of information searched would be associated with higher quality decisions, and 3.) Searching more information would be associated with better decisions (Stafford, 2004). Research Question 3.

How were the cognitive variables and task performance variables both related to decision making outcomes in a relocation task?

Hypothesis 3. Based on previous literature (Stafford, 2004), it was proposed that relations among cognitive and task performance factors would be evident. Specifically: Gc would correlate with the amount and selectivity of information searched (Stafford, 2004). WM would 
correlate with selectivity and order of information searched (Stafford, 2004). Gf would correlate with selectivity and order of information searched (Stafford, 2004).

Hypothesis 4. The conceptual decision making model (Patrick et al., 2003) (included below) was examined to determine whether the search strategies selectivity, order of information searched, and amount of information searched mediate the relationship between the cognitive variables Gf, Gc, and WM and decision quality using Baron and Kenny’s (1986) steps of establishing mediation.

Exploratory Analyses. In order to investigate further influences on decision making, exploratory analyses were conducted in order to examine the effects of gender and the type of information used on decision quality. A multiple linear regression was used to determine the effects of gender and affective information on decision quality. 


\section{Chapter III}

\section{Methods}

\section{Participant Characteristics and Recruitment}

Participants included in this study were undergraduate students from West Virginia University. Participants were recruited through the department's online recruitment system (SONA). Upon completion of the protocol, participants received one hour of extra credit that could be applied in undergraduate psychology courses. Fifty-seven individuals completed the study. However, initial inspection of the data revealed that some participants did not spend very much time on the decision-making task. Based on Patrick (1995), individuals who looked at less than ten percent of the available information were excluded from the analyses. A total of 49 individuals completed the requirements of the study and were included in data analyses.

Based on the results of a preliminary power analysis conducted in Sample Power, the sample size of 49 offered enough power (power $>.80$ ) to detect medium to large-sized effects $(f$ $=.30$ ) in the regression analyses. Further, a sample size of 50 would provide power (power approximately $=.80)$ to detect medium to large-sized effects $(f=.30)$ using up to 4 predictors in regression analyses.

A second power analysis was conducted in Sample Power for the correlations between the variables. The sample size of 49 offered insufficient power (power $<.80$ ) to detect medium to large-sized effects $(f=.30)$.

\section{Data Collection and Procedures}

The process for the current study included computerized decision-making tasks, a computerized WM measure, and paper versions of Gc, Gf, which were administered in a group setting in the Psychology Department at West Virginia University. Participants were informed of 
the purposes, procedures and confidentiality before taking part in the protocol. Participants completed informed consent forms and had the opportunity to ask any questions before beginning the procedure. All participants had full rights to skip any of the questions in the survey, and had the right to withdraw from the study at any time. Participants completed the computerized tests first. The Coglab WM span was completed first, then the computerized decision-making tasks. Following the computerized trials, participants completed Thurstone's verbal meaning measure, Raven's Advanced Progressive Matrices, and finally the demographic information. The length of the protocol was approximately one hour.

\section{Decision Vignettes}

In the two written hypothetical vignettes, the needs and resources of the target individuals were both stated and implied. Participants chose a living environment for two hypothetical individuals: Betty and Anna. The target individuals differed in needs and resources. Betty had significant physical needs, and Anna was healthy, but had social needs. The structured design of the two scenarios enables researchers to be certain that participants have equal goals for choosing the correct decision.

\section{Feature by Alternative Matrices}

Information was presented in an $(8 \times 8)$ alternative-by-feature matrix. Participants were allowed to view as much information as they wanted. Participants were permitted to view only one piece of information at a time. The matrices for the Anna and Betty scenarios are included in Appendix B. The eight housing alternatives differed based on the amount of care provided. The four types of housing arrangements were skilled nursing homes, assisted living, independent living arrangements, and congregate living. The level of care available is the highest for skilled nursing homes, then assisted living, followed by independent living, and finally congregate 
living (Golant, 1992). The eight features included regarding the housing alternatives include: 1) rent, 2) size (square feet and number of bedrooms), 3) location (setting, distance from shopping), 4) available medical services, 5) non-medical services (laundry, meals), 6) social activities (social programs, age of other residents), 7) safety features, and 8) an affective component regarding whether individuals could have pets in their homes and whether and to what extent guests could stay at their homes. The first seven features are derived from prior research suggesting that each is an important factor when choosing a new living arrangement (Everard et al., 1994; Gilderbloom \& Mullins, 1995). The affective component is based on previous research suggesting that individuals may use different strategies when solving problems that contain an emotional component (Blanchard-Fields et al., 1995).

A panel of 4 experts assisted in the development of task materials. The experts were comprised of individuals who had experience with older adults and relocation, such as a social worker, a gerontology case manager, a gerontology professor specializing in housing, and an administrator for a home health care agency. The experts had an average of 18 years working experience $(M=18, S D=15.34)$. Although seven of the features in the housing matrices have been used previously (Patrick et al., $2003 \&$ Stafford, 2004), the addition of the affective component necessitated re-evaluation of the quality rankings, feature ratings, and determination of the most relevant cells. Experts reviewed the housing scenarios and rank-ordered the features and housing options for relevance to the specific needs of the target individual. Kendall's coefficient of concordance was used in order to determine the most appropriate housing choices and features for each target individual. In the Anna scenario, the two top housing choices were alternatives one and five $(W=.37, \mathrm{p}<.05)$, and the most important features were rent, size, and safety $(W=.49, \mathrm{p}<.05)$. For the Betty scenario, the top housing choices were alternatives one, 
two, and seven $(W=.54, \mathrm{p}<.05)$, and the most important features were location, safety features, and the affective information $(W=.46, \mathrm{p}<.05)$.

\section{Procedures}

Apparatus.

Data were collected during group sessions utilizing individual computers and paper and pencil measures. Paper based versions of the Gf, and Gc measures were collected during the group sessions. The housing matrices and WM measure were presented via computer. Data collection occurred in a computer lab (room 1115) in the Psychology Department of West Virginia University. Participants each had their own computer and were able to adjust the angle and contrast of the screen according to their individual preferences.

\section{Task Implementation.}

As in Johnson (1990), Patrick (1995), Patrick et al. (2003) and Stafford (2004), information was presented via computerized alternative-by-feature matrices. The decision matrices are included in Appendix B. Participants were able to view only a single cell at a time. They then chose the desired cell by typing in the corresponding letter-number code. After the letter-number code was entered, text appeared on the screen. When the participant finished reading that information, the cells could be exited by pressing the space bar. This action returned participants to the matrix from which another information cell could be selected. Participants indicated readiness to make their final decision by pressing the 'enter' key. At that point, a prompt appeared, asking participants which housing option was their final selection. The participants then entered the single letter code to indicate their final choice.

Two practice trials were included to familiarize the participants with the matrices and the keyboard. The practice matrices varied in size: $(2 \times 3)$ and $(4 \times 4)$. Following the practice trials, 
participants were asked if they felt comfortable with the computer and if they were ready to proceed to the actual task materials. If individuals felt that they were unable to proceed to the actual task, further training would have been provided until they felt able to do so. None of the participants requested additional time to familiarize themselves with the decision matrices.

Following the practice trials, each participant completed a self-purchase housing decision using an (8 x 8$)$ alternative-by-feature matrix. Due to the inability of determining decision quality in the self-purchase condition, results of these data will not be reported. Finally, participants completed the two computerized housing decisions for the hypothetical individuals. The order of presentation of the two vignettes was counterbalanced across participants to reduce practice effects.

\section{Measures}

\section{Working Memory Span}

WM, defined by the amount of information one is able to concurrently store and manipulate (Baddeley, 1992) was assessed. WM span was chosen because research has shown that smaller WM capacity influences differences in the amount and order of information searched when information is presented in matrix format (Johnson, 1990). WM was assessed using the online Wadsworth Coglab. Five types of stimuli were assessed from Coglab, those include numbers, letters that sounds different, letters that sound the same, short words, and long words (Wadsworth Coglab, 2005). Coglab was chosen because it can be administered quickly in a group setting and utilizes a computerized format similar to the decision matrices. The Coglab test battery has been used in previous research (Spaulding, Garbin \& Dras, 1989; Voruganti, Heslegrave \& Awad, 1997), however little psychometric information is currently available. The short words measure of WM was used in analyses due to the word based presentation of the 
study's survey materials. The mean WM span was approximately 5 words $(M=5.30, S D=1)$ in the current sample.

\section{Crystallized Ability}

Gc was assessed using Thurstone's verbal meaning measure. Thurstone's verbal meaning measure consists of 16 words. Participants must read the target word then choose the correct meaning from a choice of 5 other words (Margrett, 1999). Thurstone's verbal meaning measure was chosen due to the ease at which it can be used in a group format. The verbal meaning measure has also been used repeatedly in previous research and has shown a test-retest reliability of .79 (Margrett, 1999). The mean Gc measure was about 3 words $(M=3.50, S D=1.80)$ for the current sample.

\section{Fluid Ability}

Gf was measured using Raven's Advanced Progressive Matrices (APM). The Raven’s Advanced Progressive Matrices was chosen because it can be administered via paper format along with the other measures, and also due to the ability to administer the test in a group format. The test is un-timed and consists of 36 questions. The test requires individuals to correctly identify the missing pattern when given a group of symbols. The series becomes progressively more difficult as individuals correctly solve the patterns (Wilderdom, 2005). Raven's Advanced Progressive Matrices have shown internal consistency coefficients ranging in the .80's and .90's (Wilderdom, 2005). Test-retest reliability ranges between .70 and .90 (Wilderdom, 2005). For the current sample the mean number correct was $32(M=32.02, S D=2.80)$. 


\section{Information search strategies}

Three information search strategy measures were derived based on completion of the computerized tasks: amount of information searched, order of information searched, and search selectivity.

\section{Amount}

Amount of information searched was assessed as the proportion of the total number of pieces of information viewed, including those pieces viewed more than once, divided by the number of available pieces of information (Johnson, 1990; Payne, 1976). This measure may exceed 1.0 in magnitude if a decision maker views a significant number of information pieces more than once. The total number of pieces of information available to participants is 64 .

\section{Feature-based order}

Feature-based order of information searched was assessed with a ratio of repetition $(R R)$ measure (Patrick et al., 2003). The RR is used in order to examine the order in which the participant views the information. The RR is computed by dividing the total number of repetitions by the possible number of repetitions. When decision makers search within a column to compare different alternatives on only one feature (e.g. A1, B1, C1, A2), the result is a high RR (2 feature repetitions / 3 possible repetitions $=.67)$, (Patrick et al., 2003). A high RR results if a decision maker searches only the price column for all of the housing options. When decision makers search across different features in only one row (e.g., A1, A2, A3, B1), the RR would be low $(0$ feature repetitions / 3 possible repetitions $=0$ ) (Patrick et al., 2003). A low RR would occur if a person searched across only one alternative, such as looking at all the features for only one housing option. 
Researchers can examine order of information searched at different times during the search process to observe how the decision maker's search process changes across time. However, the average RR across the two scenarios was used in analyses in the current study due to constraints on power. Feature-based order of information searched was used in analyses because it is typically indicative of a non-compensatory search strategy, which is typically used during high demand decision-making scenarios (Olshavsky, 1979; Payne, 1976).

\section{Selectivity of Search}

Search selectivity refers specifically to which pieces of information are viewed. Selectivity was operationalized as the number of important pieces of information the participant searches. Selectivity was computed as the proportion of important cells viewed out of the total pieces of information the decision maker viewed. Relevance was determined by how valuable each piece of information is based on the needs of the hypothetical person. The important cells were derived based on the choices of the expert panel. The top choices of the alternatives and features were combined in order to determine the most important cells for each hypothetical individual. For example, the expert panel chose alternatives one and five as the best choices in the Anna scenario, while they chose rent, size, and safety as the most important features. Therefore, the most important cells in the Anna scenario were rent for alternative one, size for alternative one, safety for alternative one, rent for alternative five, size for alternative five, and safety for alternative five. The most important cells in the Betty scenario were location for alternative one, safety features for alternative one, affective information for alternative one, location for alternative two, safety features for alternative two, affective information for alternative two, location for alternative seven, safety features for alternative seven, and the affective information 
for alternative seven. The best choices, features, and cells that were chosen based on the expert panel are bolded in Appendix B for convenience.

\section{Decision Quality}

Decision making quality was assessed as the dependent variable in the proposed study. Similarly to previous decision-making research, the participant's choices were coded and assessed to determine if they agree with the rank ordering of the expert panel (Bagozzi \& Dholakia, 1999; Yates \& Patalano, 1999). Numbers were assigned to participants' choices based on their agreement with the expert panel. For example, the top two housing choices were alternatives one and five for the Anna scenario. Therefore, if a participant chose option one, they were given a one, and if they chose option five, they were given a two. 


\section{Chapter IV}

\section{Results}

\section{Descriptive Results}

A summary of the sample is presented in Table one. The mean age of the sample was approximately 21 years old $(M=20.80, S D=2.82)$. All 49 participants were enrolled in West Virginia University during the Fall 2006 semester and received extra credit in a psychology class for their participation. Approximately $82 \%(\mathrm{~N}=40)$ of the sample was female, and approximately $18 \%(\mathrm{~N}=9)$ was male. Forty-one percent $(\mathrm{N}=20)$ of the sample reported that they had only completed high school, $12 \%(\mathrm{~N}=6)$ were sophomores in college, $12 \%(\mathrm{~N}=6)$ were juniors in college, $31 \%(\mathrm{~N}=15)$ were seniors in college, and $4 \%(\mathrm{~N}=2)$ reported that they had already obtained a bachelor's degree.

\section{Preliminary Analyses}

Prior to data analyses, a paired t-test was used to compare decision quality for each scenario to determine if decision quality differed by scenario. Paired $t(48)=.09$, ns., indicating that quality did not differ by scenario. Therefore, decision quality across the two scenarios was combined into a single index and used in subsequent analyses. Decision quality across the two scenarios served as the dependent variable in analyses. Participants made one of the two best choices approximately 50\% in both the Anna and Betty scenarios.

Paired t-tests were conducted on the amount of information viewed, search selectivity, and the feature-based RR of each vignette. Paired $t(48)=.23$, ns., indicated that the amount of information viewed did not differ by scenario. The average amount of information viewed was 50 pieces $(S D=21.50)$. Therefore, the amount of information viewed across the two scenarios was combined into a single index that was used in the regression analysis and subsequent 
analyses. Paired $t(47)=-1.6$, ns., indicated that selectivity did not differ by scenario either. The average amount of selective information viewed was approximately $4 \%(M=.04, S D=.03)$. Search selectivity was also combined into a single index that was used in subsequent analyses. Paired $t(47)=-3.4, \mathrm{p}<.05$, indicated that the feature-based RR differed across scenarios. Therefore, the RR's for the Betty and Anna scenarios were entered into the regression equation separately.

Research Questions and Hypotheses

To address research question one, how are cognitive variables related to decision making outcomes in a relocation task, it was hypothesized that cognitive abilities, specifically, Gf, Gc, and WM would be associated with better decision quality. Hypothesis one is based on Stafford (2004), in which Gf, Gc, and WM predicted higher quality decisions.

Correlations between the variables are presented in Table two. Before the regression was performed, the independent variables Gf, Gc, and WM were examined for multicollinearity. Results of the multicollinearity tolerance (all greater than .75), and the variance inflation factor (all less than 1.4) indicated that the estimated unstandardized $\beta$ s of the independent variables Gf, Gc, and WM were stable in the regression model for hypothesis one (Howell, 2002). As seen in Table three, the overall model was not significant, $F(3,45)=1.09$, ns. The equation accounted for only $6.7 \%$ of the variance in decision-making outcomes. Neither of the cognitive variables Gf, $(\beta=-.02$, ns. $)$, Gc, $(\beta=-.07$, ns. $)$, nor WM, $(\beta=.23$, ns. $)$, surfaced as a unique predictor of decision quality in the final model. Thus, hypothesis one was not supported, in that Gf, Gc, and WM were not associated with higher quality decisions.

Research Question two asked how information search strategies were related to decisionmaking outcomes in a relocation task. Specifically, it was suggested in hypothesis two that the 
task performance variables such as search selectivity (Patrick et al., 2003, \& Stafford, 2004), feature-based order of information searched, and amount of information searched (Stafford, 2004) would influence decision quality. Specifically, increased search selectivity (Patrick et al., 2003; Stafford, 2004), feature-based order of information searched, and amount of information searched would be associated with higher quality decisions (Stafford, 2004).

Search selectivity was not entered into the regression analysis due to constraints on power. Results of the power analysis suggested that using three predictors would provide power $>.80$, therefore the search strategy variables used in previous literature were entered into the regression analysis for hypothesis two (Johnson, 1990; Olshavsky, 1979; Payne, 1976). Amount of information searched, feature-based order of information searched for Betty, and featurebased order of information searched for Anna were the independent variables entered into the regression analysis.

Prior to the regression analysis, the independent variables amount of information searched, feature-based order of information searched for Betty, and feature-based order of information for Anna were examined for multicollinearlity. Results of the multicollinearity tolerance (all greater than .75), and the variance inflation factor (all less than 1.4) indicated that the estimated $\beta^{\mathrm{s}}$ s of the independent variables were not stable in the regression for hypothesis two (Howell, 2002). As seen in Table four, the overall model was not significant, $F(3,44)=.24$, ns. The equation accounted for approximately $9 \%$ of the variance in decision-making quality. Neither amount of information searched, $(\beta=.32$, ns. $)$, feature-based order of information searched in the Betty scenario, $(\beta=.11, \mathrm{~ns}$.$) , nor feature-based order of information searched in$ the Anna scenario $(\beta=.10, \mathrm{~ns}$.$) , surfaced as unique predictors of decision quality in the final$ model. Hypothesis two was not supported, in that amount of information searched, feature-based 
order of information searched in the Betty scenario, and feature-based order of information searched in the Anna scenario were not associated with higher quality decisions.

Research Question three asked how cognitive variables and information search strategies together related to decision quality in a relocation task. Specifically, hypothesis three suggested that Gf and WM would correlate with selectivity and the order of information searched, and Gc would correlate with the amount and selectivity of information searched (Stafford, 2004). The cognitive variables were entered in the second step of the regression analysis because it was hypothesized that the cognitive variables influence the search strategies (Stafford, 2004).

The complete model for hypothesis three could not be tested due to inadequate power. Results of the power analysis indicated that using three variables would provide adequate power (power $>.80$ ). Therefore, based on the correlations in Table two, the strongest predictor of decision quality out of the cognitive abilities and search strategies was entered into the regression equation for hypothesis three. WM had the highest correlation with decision quality $(r=.25, \mathrm{~ns}$. $)$ out of the cognitive variables. Amount of information searched had the highest correlation with decision quality $(r=.21, \mathrm{~ns}$.) out of the search strategy variables.

Before the hierarchical regression was performed, the independent variables WM, and amount of information searched were examined for multicollinearity. Results of the multicollinearity tolerance (all greater than .75), and the variance inflation factor (all less than 1.4) indicated that the estimated $\beta^{\mathrm{s}} \mathrm{s}$ of the independent variables WM and amount of information searched were stable in the regression analysis for hypothesis three (Howell, 2002). As seen in Table five with decision quality as the outcome variable, Step one of the model with amount of information alone was not significant, $F(1,27)=.20$, ns. The equation accounted for $3.5 \%$ of the variance in decision quality. In step two, the addition of WM as a predictor also resulted in a 
non-significant model, $F(1,46)=.11$, ns. This equation accounted for an additional $5.3 \%$ of the variance in decision quality. Addition of the cognitive variables to the equation resulted in a nonsignificant increment in $R^{2}, \Delta F(1,46)=2.70$, ns. After equation two, the model accounted for $8.8 \%$ of the variance in decision-making quality.

Amount of information searched $(\beta=.20$, ns.) was not a unique predictor of decision quality in step one of the model. Similarly, neither amount of information searched $(\beta=.16, \mathrm{~ns}$.), nor WM $(\beta=.23, \mathrm{~ns}$.$) , surfaced as a unique predictor of decision quality in step two of the final$ model. Interaction terms were not analyzed because it is unlikely that individuals with low cognitive abilities would show exceptional task performance and vice versa. Hypothesis three was not supported, in that there were no significant relations among WM and the amount of information viewed.

Hypothesis four addressed the relationship between the search strategies and the cognitive variables, specifically; it was hypothesized that the search strategies selectivity, order of information searched, and amount of information searched would mediate the relationship between the cognitive variables Gf, Gc, and WM and decision quality.

Due to lack of support for hypotheses one, two, and three, hypothesis four could not be analyzed. Baron and Kenny's (1986) steps to establish mediation require first that the initial variable be related to the outcome. The cognitive variables did not predict decision quality in the current study; therefore there was no relationship that could be examined. Step two requires that the initial variable be related to the mediator. The cognitive variables did not predict the search strategies, indicating again that there is no mediation relationship to be tested. Step three involves showing that the mediator affects the dependent variable. Here step three would have used both the cognitive variables and the search strategy variables together to predict decision 
outcomes. Using a regression analysis, the cognitive variables would have been entered into step one, and then the search strategy variables would have been entered into step two. Entering the cognitive variables first serves to control them while establishing the effect of the mediator on decision outcomes. Step four involves examining the $\beta^{\prime}$ s and tests on the $\beta$ s in order to determine whether partial or complete mediation occurred.

The exploratory analyses examined whether and to what degree gender and the affective information influenced decision quality.

Prior to the exploratory regression analysis, a paired t-test was conducted on the amount of affective information viewed for the Anna and Betty scenarios to determine if there were differences in the amount of information viewed. Paired $t(48)=2.80, p<.05$, indicating that the amount of affective information viewed significantly differed by vignette. Participants viewed approximately two pieces of affective information in the Betty scenario $(M=1.70, S D=2.16)$, and approximately one piece of information in the Anna scenario $(M=.80, S D=1.10)$. Therefore, the amount of affective information viewed for Anna and Betty was separated for entry into the regression analysis.

Upon further inspection of the affective information viewed for each vignette, it appeared as if the differences in affective information viewed may have been due to the financial constraints in the Anna scenario. There were only two possible scenarios out of eight that could be afforded based on Anna's income. Due to the financial constraints, participants where probably more motivated to chose a location that was affordable and met the target's needs over a location that met the affective needs of the hypothetical person. The Betty scenario, on the other hand, stated that she has a good income, so price would not be as important in this scenario. Participants would be more likely to view the affective information in the Anna 
scenario because finances do not restrict her choice. Anna could choose to spend more money on a home that met her affective needs. Due to the differences in the amount of affective information viewed in each scenario, only the affective information viewed in the Betty scenario was included in the exploratory regression analysis. The affective information viewed in the Betty scenario appeared to be more relevant in predicting decision quality than in the Anna scenario.

Before the exploratory regression predicting decision quality was completed, the independent variables gender and affective information were examined for multicollinearity. Results of the multicollinearity tolerance (all greater than .75), and the variance inflation factor (all less than 1.4) indicated that the estimated unstandardized $\beta^{\mathrm{s}} \mathrm{s}$ of the independent variables were stable in the regression model for the exploratory analyses (Howell, 2002). As seen in Table 6 , the overall model was significant, $F(2,46)=3.40, \mathrm{p}<.05$. The model accounted for approximately $36 \%$ of the variance of decision-making outcomes. Gender, $(\beta=-.20$, ns. $)$, did not significantly account for decision quality. However, the affective information viewed in the Betty scenario, $(\beta=.30, \mathrm{p}<.05)$, did uniquely predict decision-making outcomes. This significant positive relation suggests that a higher amount of affective information viewed is related to higher quality decisions.

\section{Additional Analyses}

\section{Search Strategies and Decision Quality}

Post-hoc analyses further examined the relations between the search strategy variables and decision quality. Due to power constraints, all of the search strategy variables could not be simultaneously entered into the regression equation in hypothesis two. Search selectivity and amount of information searched were entered into a post-hoc regression analysis based on 
previous literature suggesting that amount of information searched and search selectivity are associated with higher quality decisions (Patrick, 1995, Patrick et al., 2003, \& Stafford, 2004). A multiple linear regression was used to examine the relations among the search strategy variables amount of information searched and search selectivity, and the dependent variable decision quality. Prior to the regression analysis, the independent variables amount of information searched and search selectivity were examined for multicollinearity. Results of the multicollinearity tolerance (all less than .75), and the variance inflation factor (all greater than 1.4) indicated that the estimated unstandardized $\beta$ s of the independent were stable in the regression (Howell, 2002). As seen in Table seven, the overall model was not significant, $F(2$, $46)=.44$, ns. The equation accounted for only approximately $4 \%$ of the variance in decisionmaking quality. Neither search selectivity $(\beta=.-.03$, ns.), nor amount of information searched $(\beta$ $=.20$, ns.) uniquely predicted decision quality in the final model. Search selectivity and amount of information searched were not associated with higher quality decisions.

\section{Relations Among the Cognitive and Search Strategy Variables}

Post-hoc analyses further examined the relations among the cognitive and search strategy variables. Due to inadequate power, all of the cognitive and search strategy variables could not be simultaneously entered into the hierarchical regression equation for hypothesis three. Pearson correlations between the cognitive and search strategy variables were conducted in order to examine the hypothesized relations from hypothesis three. Hypothesis three was based on Stafford (2004) and suggested that Gf and WM would correlate with search selectivity and feature-based order of information searched. It was also hypothesized that Gc would correlated with the amount of information searched and search selectivity. 
Correlations between the variables are presented in Table eight. The correlation between Gf and search selectivity was, $r=-.01$, ns. The correlations between Gf and feature-based order of information searched were: feature-based order for Betty, $r=.17$, ns. and feature-based order for Anna, $r=-.04$, ns.

The correlation between WM and search selectivity was, $r=-.12$, ns. The correlations between WM and feature-based order of information searched were: feature-based order for Betty, $r=-.07$, ns. and feature-based order for Anna, $r=.09$, ns.

The correlation between Gc and amount of information searched was, $r=.03$, ns., and the correlation between Gc and search selectivity was, $r=.22$, ns. No significant positive relations were found among the cognitive variables and the search strategy variables. 


\section{Chapter V}

\section{Discussion}

The purpose of the study was to examine the roles of cognitive abilities and search strategies in a hypothetical relocation decision in order to determine whether and to what extent these variables predicted decision-making quality. This study sought to examine the cognitive abilities Gf, Gc, and WM in relation to decision quality in a relocation task. This study also sought to examine the search strategy variables amount of information searched, feature-based order of information searched, and search selectivity in relation to decision quality in a relocation task. Finally, this study sought to examine the relations among the above listed cognitive variables and search strategy variables. A novel affective component was also added to the decision task in order to examine the relation among affective information and decision quality.

The main findings of this study include: 1) The cognitive components Gf, Gc, and WM were not associated with higher quality decisions; 2) The task performance variables amount of information searched, selectivity, and feature-based order of information searched were not associated with higher quality decisions; 3) There were no significant relations between the cognitive variables and the task performance variables; and 4) The amount of affective information viewed in the Betty scenario was significantly positively associated with decision making quality. It is important to note however, that the results of this study should be interpreted with caution due to the lack of power. It is possible that significant results were not found due to type II error.

Cognitive Abilities and Decision Outcomes. Non-significant results were found in the examination of the association between the cognitive variables and decision quality. Gc, Gf, and WM did not significantly account for higher quality decisions. Further, neither of the cognitive 
variables uniquely predicted decision quality. Previous studies have found a significant positive relationship between Gf, Gc, and WM. These studies have found that WM surfaced as a significant unique predictor of decision outcomes (Patrick et al., 2003; Stafford, 2004). Diehl et al. (1995) found that out of the cognitive variables Gf and Gc, Gf was the most salient predictor of problem solving in a task involving activities of daily living.

Although the Gf and Gc scores in this study were consistent with previous research indicating that younger adults have higher Gf and lower Gc than middle age or older adults (Ackerman \& Rolfus, 1999), it is possible that significant positive relations among the cognitive variables and decision quality were not evident due to the ceiling and floor effects that occurred with the Gf and Gc measures. A ceiling effect was evident in the Gf measures, in which participants scored and average of 32 correct out of a possible 36 . Conversely, a floor effect was found in the Gc measure, in which participants scored an average of only 3.5 words correct out of 16 possible. It is possible that the floor effects found in the Gc measure were due to a cohort difference. The average age of participants was approximately 21 years in the current study; therefore, it is less likely that younger adults would know the meanings of these somewhat archaic words. Thurstone's verbal meaning measure may be more relevant to use in studies that assess older adult's decision-making outcomes.

The ceiling effect that emerged in the Gf measure indicates that the younger adults in this study performed very well in terms of their problem-solving ability. Further, the sample had an average education of approximately 13.4 years, indicating that the sample was educated. This population of individuals should have been able to perform well based on their Gf scores, WM capacity, and their level of education, but only $50 \%$ of individuals ever made a moderately good or correct decision. Perhaps the decision tasks presented to these younger adults were not 
relevant to their lives. They may have performed better if the hypothetical person relocating was someone closer to their own age. Thus, conducting this type of research with younger adults may require a task that is more ecologically valid for their age range.

Search Strategies and Decision Outcomes. Non-significant results were found in the examination of the association between the search strategies and decision quality. Amount of information searched and feature-based order of information searched did not significantly account for higher-quality decisions. Similarly, neither amount of information searched nor feature-based order of information searched uniquely accounted for decision quality.

Stafford (2004), found that when individuals search through more pieces of information they are more likely to make a good decision. Patrick et al. (2003), on the other hand, found two pathways to quality decisions. Individuals who viewed fewer pieces of highly selective information were more likely to make a good decision, while individuals who looked at a lot of information were also more likely to make a good decision. The second pathway found by Patrick et al. (2003) involves individuals looking at massive amounts of information in order to make their decision. In this case, they aren't looking at selective information only, but they are looking at the majority of all the information available to them. The younger adults in this study viewed an average of 50 pieces of information. The minimum number of cells viewed in this study was 18 and the maximum number of cells viewed was 125 . It is interesting that there is such a large range in the amount of cells viewed by the younger adults. Johnson (1990) found that the younger adults in her study were more likely to view more pieces of information when making a decision, and also that they were more likely to review pieces of information than their older counterparts. However, the time spent on task was not significantly different (Johnson, 1990). Patrick et al. (2003) found that older adults looked at less information, but the information 
that they viewed was highly selective. Johnson (1990) found that compared to younger adults, older adults spent more time looking at fewer pieces of information. It is possible that in the current study the younger adults were performing in a manner similar to in Patrick et al. (2003), and Johnson (1990) by viewing a lot of information, but they quit searching before they viewed enough of the important information needed to make a correct decision for the hypothetical individuals. It is possible that they didn't search through enough information needed to make a good decision about where the hypothetical individuals should move because they were not motivated to do so. They may not have been concerned about making a good decision, but instead of finishing the protocol as quickly as they could. This lack of motivation may have led participants to respond carelessly when looking at information and choosing a new residence. The computerized format of relocation decisions may not have captured the decision-making ability of younger adults adequately.

Stafford (2004) also found that feature-based order of information searched was significantly positively associated with higher quality decisions. Results of the current study are inconsistent with Stafford (2004), in that feature-based order of information searched was not associated with better decisions. This may be explained in part due to the fact that the younger adults in this study may not have been familiar with the needs of the hypothetical older adults or the available housing options. Instead of narrowing in on a few housing options and then comparing the features of each one, participants may have been looking at all of the features available in the different housing alternatives, producing an alternative-based order of information searched. Stafford (2004) found that individuals who used a feature-based order of information searched were more likely to make a correct decision; however, the participants were older adults. Participants in the current study may have adopted an alternative-order of 
information search that would be consistent with Johnson (1990), in which younger adults were more likely to view more pieces of information searched and to review information more than older adults. It is possible that feature-based order of information searched may not predict decision outcomes in younger adult samples due to the findings of Johnson (1990). Whether and to what extent feature-based or alternative-based order of information searched predicts decisionmaking outcomes may depend largely on the age of the decision makers.

Post-Hoc Analyses: Search Strategy Variables and Decision Quality. Additional analyses were conducted on the hypothesized relations among the search strategy variables and decision quality due to constraints on power. All of the cognitive variables could not be entered simultaneously into the regression analyses in hypothesis three. Therefore, the search strategy variables amount of information searched and search selectivity were entered into a post-hoc multiple linear regression. Non-significant results were found in the examination of the association between the search strategies amount of information searched, search selectivity and decision quality. Amount of information searched and search selectivity did not significantly account for higher-quality decisions. Similarly, neither amount of information searched nor search selectivity uniquely accounted for decision quality.

Previous studies have found a significant positive relationship between search selectivity and decision quality (Patrick et al., 2003; Stafford, 2004). Perhaps the younger adults in this study did not know which of the cells were pertinent to view when making relocation decisions for a hypothetical older adult. Further, the younger adults probably were not familiar with the different living settings and medical options that were available to the hypothetical individuals. If participants did not know which of the cells were relevant to the hypothetical older adults, this may explain why selectivity did not predict decision making in the current study. Again, it is 
expected that participants may have performed better if the hypothetical individuals used in the study were young adults.

Cognitive Variables and Search Strategies. Non-significant results were found in the examination of the association between the cognitive variable WM and the task performance variable amount of information searched. These two independent variables were chosen for hypothesis three because they were the strongest predictors of decision quality out of the cognitive variables and the search strategy variables. Further, results of a power analysis indicated that using up to three variables would provide sufficient power (power $>.80$ ). The hypothesized relations from hypothesis three were further examined using post-hoc analyses. Post-Hoc Analyses: Cognitive Variables and Search Strategies. Additional analyses further examined the relations among the cognitive and search strategy variables. Due to constraints on power, all of the cognitive and search strategy variables could not be entered simultaneously into the hierarchical regression in hypothesis three. Therefore, pearson correlations were conducted in order to examine the hypothesized relations from hypothesis three. Hypothesis three was based on Stafford (2004) and suggested that Gf and WM would correlate with search selectivity and feature-based order of information searched. It was also hypothesized that Gc would correlated with the amount of information searched and search selectivity.

Gf and WM were not significantly associated with selectivity or feature-based order of information searched. Further, Gc was not significantly associated with the amount of information searched or search selectivity. Previous research has found that Gf and WM were significantly positively associated with search selectivity and feature-based order of information 
searched. This research has also indicated that Gc was significantly positively associated with amount of information searched and search selectivity (Stafford, 2004).

Previous research has indicated that cognitive variables are related to search strategies. Johnson (1990) found that cognitive abilities were related to the amount of information searched and search strategies. Stafford (2004) found that the cognitive abilities Gf, Gc, and WM were related to the selectivity of information searched. Further, WM surfaced as the only unique variable to predict decision quality. Previous research has also indicated that cognitive variables are related to decision quality. Patrick et al. (2003) and Stafford (2004) both found that WM was directly related to decision outcomes. Finally, previous research has also linked search strategies to decision quality. Patrick et al. (2003) found that lower amounts of information searched and increased search selectivity were significantly associated with decision making outcomes. Stafford (2004) found that higher amounts of information searched and increased search selectivity were significantly associated with decision outcomes. Based on these relationships between cognitive abilities, search strategies, and decision quality, it was hypothesized that the search strategy variables would have mediated the relationship between the cognitive variables and decision outcomes. This study extends prior decision-making research in its attempt to test for mediation using the conceptual decision-making model mentioned previously. It is the first known to test such a relationship. Due to non-significant results however, the model could not be analyzed. Future studies should attempt to test the included model and other possible mediators between cognitive variables and decision outcomes to more accurately understand the processes behind decision making.

It is likely that the ceiling and floor effects mentioned previously concerning the cognitive variables Gf and Gc affected the results of hypothesis three. These measures may not 
have been accurate indicators of participants' Gf and Gc, thus making the results of this study difficult to interpret. Participants may not have been familiar with the housing options, medical services, or Medicaid/Medicare coverage and reimbursement. Unfamiliarity with the needs of older adults may explain why some of the participants in the current study viewed various pieces of information. They may have been reviewing information in hopes of eventually narrowing their options down to an appropriate choice. Unfamiliarity with the needs of older adults may also explain why some of the individuals viewed few pieces of information. They may have failed to view information in the matrices because they were unaware of what to look for. Further, participants may have been unmotivated to take the time to carefully view information and make a good decision. Carelessly rushing through the decision task or not looking through a sufficient amount of information may have contributed to the lack of correct decisions in the study.

Mediation Between Search Strategies and Decision Making. Baron and Kenny's (1986) conditions to establish mediation were not satisfied in the current study, therefore it was not possible to test the mediation relationship between the search strategies and decision making outcomes. Step one requires that the initial variable be related to the outcome variable. The cognitive variables did not predict decision quality; therefore it was not possible to conduct step one, indicating that there was no mediation model that could be tested. Step two requires that the initial variable be related to the mediator. Again, the cognitive variables did not predict the search strategies in the current study; therefore step two could not be conducted.

Affective Information and Decision Outcomes. Interesting results emerged in the exploratory examination of the relations among gender, affective information, and decision quality. Gender was not significantly associated with decision quality, but the affective 
information viewed in the Betty scenario did significantly account for decision quality. As noted previously, there were differences in the amount of affective information viewed in the Anna and Betty scenarios. Participants viewed more information in the Betty scenario than in the Anna scenario. This is most likely because there were only two housing options out of eight that Anna could afford based on her income. However, the Betty scenario implied that she was well off and that money was not an option when choosing a place for her to live. Therefore, it is probable that participants noticed this difference in financial constraints between the two scenarios and adjusted the amount of affective information that they viewed for each hypothetical individual. Due to the financial constraints and lack of affective information viewed in the Anna scenario, only the affective information viewed in the Betty scenario was entered into the exploratory regression. The affective information viewed in the Betty scenario did significantly account for decision quality, in that individuals who viewed more affective information were more likely to make a correct decision.

It is possible that the addition of the affective component in the current study affected the results of the study. Since the affective information has not been included in previous decisionmaking research, researchers may not know how individuals process this type of information when they are making important decisions. Blanchard-Fields et al., (1995) found that emotional salience affected the problem solving style that participants used. It is possible that the addition of the affective component changed participants' decision-making strategy, which in turn may have affected results of the study. The addition of the affective component may make this task more ecologically valid and lifelike, thus creating results that are different from previous decision-making research. 
Significant Findings. The addition of the affective information to the body of decisionmaking literature is an addition and extension of the decision making research. This study is the first to include such information in research that addresses relocation and decision making abilities, as most research relies on quantitative information such as size and price, neglecting the areas of autonomy and emotion. The affective information in this study involved whether and to what extend the hypothetical older adults could have visitors stay at their homes and also whether they could have pets. These components were added to the current study in order to determine if they would surface as important factors in determining where the hypothetical individuals should move. The amount of affective information viewed in each vignette was statistically different. Participants viewed approximately two pieces of the affective information in the Betty scenario, while they only viewed one piece in the Anna scenario. Further, the affective information surfaced as a significant positive predictor of decision quality in the Betty scenario, while it was not examined for the Anna scenario. As discussed previously, the information was not examined in the Anna scenario due to the financial constraints on Anna. Since Betty was well off, it would be more likely that participants would view the affective information, because she could afford to choose a place based on whether she could have a pet and visitors stay, and Anna could not. The $\beta$ of the affective information indicated that participants who viewed the affective information in the Betty scenario were more likely to make a correct decision than individuals who did not view the affective information $(\beta=.30, p<.05$, $\left.R^{2}=.36, p<.05\right)$. The affective component was important for participants to view when making a decision of where Betty should live. Future decision-making research should seek to add an affective component available for participants to view. The affective component may make this area of decision-making research a more ecologically valid task. Perhaps the affective 
component changed the way participants viewed and thought about the information that was presented to them, this in turn may have produced results that are inconsistent with Patrick et al. (2003), \& Stafford (2004), which were discussed previously.

Limitations and Future Research. The sample size of 49 may be problematic in that results were close to not having adequate power of .80 . It is possible that the results may have been affected by insufficient power. The lack of power makes it less likely that significant results can be detected if there are any, therefore, it is possible that significant results were not found due to Type II error. The sample also was a convenience sample comprised all of undergraduates who were taking psychology classes during the Fall 2006 semester. This may have brought bias into the study results. Further, the majority of the sample (82\%) was female. The size of the male sample limits any conclusions that can be drawn about gender differences. The lack of males in the study may have prevented the detection of gender differences if there were any. Future studies should obtain larger sample sizes in order to have enough power to detect results. Further, future studies should seek to obtain equal numbers of individuals from each gender and a more heterogeneous sample representative of the student population.

The ceiling and floor effects evident in the cognitive measures may be problematic for results. The floor effect that occurred with the Gc measure makes it hard to draw conclusive results concerning the cognitive ability Gc. The words included on the Gc measure may not be very relevant to the sample, which had an average age of 21 years old. Participants performed very poorly on the Gc measure, making it look like they have low Gc abilities, which is most likely not the case because these individuals were educated college students. The Thurstone's Gc measure most likely would have been more relevant and produced more accurate results had it been used with an older adult population. Future studies conducting decision-making research 
with younger adults should use another Gc measure that is more applicable to younger generations. Using a more relevant Gc measure will make it more likely to attain accurate measures of participants' Gc ability.

The ceiling effect that occurred with the Gf also makes it difficult to draw conclusive results concerning the cognitive ability Gf. Participants performed very well on the Gf measure with an average score of 32 correct out of 36 . This high score on the Gf measure may wash out any results that would have been significant if the participants had lower scores. Having an average score that was so high makes it look like everyone performed the same, when in actuality many participants could have Gf scores that go beyond what can be captured with the Gf measure used. Any differences that may have been evident in participants' problem-solving ability were unobserved due to lack of variation in the Gf measure. Perhaps the Gf measure used in the current study was too easy for the participants. Future studies could use another Gf measure, perhaps one that is more difficult, in order to more accurately reflect whether cognitive abilities predict decision quality. 


\section{References:}

Ackerman, P. (2000). Domain specific knowledge as the "dark matter" of adult intelligence: Gf/Gc, personality and interest correlates. Journal of Gerontology, Psychological Sciences, 55B, $69-84$.

Ackerman, P. \& Rolfhus, E. (1999). The locus of adult intelligence: Knowledge, abilities, and nonability traits. Psychology and Aging, 14, $314-330$.

Baddeley, A. (1992) Working memory. Science, 255, 556-559.

Baddeley, A. (1998). Treating memory problems. Human Behavior (pp. 311 - 324). Boston: Allyn \& Bacon.

Bagozzi, R.P. \& Dholakia, U. (1999). Goal setting and goal striving in consumer behavior. Journal of Marketing, 63, 19 - 23.

Baron, R. M., \& Kenny, D. A. (1986). The moderator-mediator distinction in social psychological research: Conceptual, strategic, and statistical considerations. Journal of Personality and Social Psychology, 51, 1173-1182.

Blanchard-Fields, F., Jahnke, H. C., \& Camp, C. (1995). Age differences in problem-solving style: The role of emotional salience. Psychology and Aging, 10, 173 - 180.

Diehl, M., Willis, S. L., \& Schaie, K. W. (1995). Everyday problem solving in older adults: Observational assessment and cognitive correlates. Psychology and Aging, 10, 478 - 491.

Einhorn, H. J. (1971). Use of nonlinear, noncompensatory models as a function of task and amount of information. Organizational Behavior and Human Performance, 6, 1 - 27.

Everard, K., Rowles, G. D., \& High, D. M. (1994). Nursing home room changes: Toward a decision-making model. The Gerontologist, 34, 520 - 527. 
Gilderbloom, J. I. \& Mullins, R. L. (1995). Elderly housing needs: An examination of the Americans housing survey. International Journal of Aging and Human Development, 40, $57-72$.

Golant, S. M. (1992). Housing America's elderly: Many possibilities/few choices. Newbury Park: Sage.

Horn, J., \& Cattell, R. (1966). Refinement and test of the theory of fluid and crystallized general intelligences. Journal of Educational Psychology, 57, 253-270.

Howell, D. (2002). Statistical methods for psychology. Fifth edition. Duxbury: Pacific Grove, CA.

Johnson, M.M.S. (1990). Age differences in decision-making: A process of methodology for examining strategic information processing. Journal of Gerontology, 45, 75 - 78.

Margrett, J. (1999). Collaborative cognition and aging: A pilot study. Unpublished doctoral dissertation, Wayne State University, Detroit, MI.

Neisser, U., Boodoo, G., Bouchard, T.J., A.W., Brody, N., Ceci, S.J., Halpern, D.F., Loehlin, J.C., Perloff, R., Sternberg, R.J., \& Urbina, S. (1996). Intelligence: Knowns and unknowns. American Psychologist, 51(2), 77 - 101.

Olshavsky, R. (1979). Task complexity and contingent processing in decision making: A replication and extension. Organizational Behavior and Human Performance, 24, 300316.

Patrick, J.M.H. (1995). Effects of age and expertise in decision making processes and outcomes. Unpublished doctoral dissertation, The University of Akron, Akron, $\mathrm{OH}$. 
Patrick, J., Spencer, M., \& Johnson, J. (2003). Information search processes and decisionmaking quality in an everyday consumer task. Unpublished manuscript, West Virginia University, Morgantown, WV.

Payne, J.W. (1976). Task complexity and contingent processing in decision-making: An information search and protocol analysis. Organizational Behavior and Human Development, 16, $366-387$.

Schaie, K. W. (1996). Intellectual development in adulthood. In J.E. Birren \& K. W. Schaie (Eds.) Handbook of the psychology of aging, $4^{\text {th }}$ edition (pp. 266 - 286). New York: Academic Press.

Sonntag, L. (2006). Religiousness and spirituality in decision-making processes and outcomes. Unpublished master's thesis, West Virginia University, Morgantown, WV.

Spaulding, W., Garbin, C. P., \& Dras, S. R. (1989). Cognitive abnormalities in schizophrenic patients and schizotypal college students. Journal of Nervous and Mental Disorders, 12, $717-728$.

Stafford, B. (2004) Gc, Gf, \& WM in relation to decision quality and selectivity. Unpublished manuscript, West Virginia University, Morgantown, WV.

Thorton, W. J. \& Dumke H. A. (2005) Age differences in everyday problem-solving and decision-making effectiveness: A meta-analytic review. Psychology and Aging, 20(1), 85 -99 .

Wadsworth Coglab online laboratory. Retrieved October 19, 2005, from http://coglab.wadsworth.com

Wilderdom (2005). Examples of intelligence tests. Retrieved October 13, 2005, from http://www.wilderdom.com/intelligence/IQExampleTests.html 
Voruganti, L. N. P., Heslegrave, R. J., \& Awad, A. G. (1997). Neurocognitive correlates of positive and negative syndromes in schizophrenia. Canadian Journal of Psychiatry, 42, $1066-1071$.

Yates, J.F. \& Patalano, A.L. (1999). Decision making and aging. In D.C. Park, R.W. Morrell, \& K. Shifren (Eds.), Processing of medical information in aging patients: Cognitive and human factors perspectives (pp. 31 - 54). New Jersey: Erlbaum. 


\section{Tables}

Table 1

Summary of Variables

\begin{tabular}{lrrrr}
\hline Variable & $M$ & $S D$ & Min & Max \\
\hline Age in years & 20.80 & 2.82 & 18.00 & 35.00 \\
Education in years & 13.44 & 1.40 & 12.00 & 16.00 \\
Gc score & 3.50 & 1.80 & 0.00 & 8.00 \\
Gf score & 32.02 & 2.80 & 22.00 & 36.00 \\
WM span & 5.30 & 1.00 & 3.00 & 7.00 \\
Total time in seconds & 162.52 & 64.64 & 53.20 & 259.22 \\
Total pieces viewed & 50.40 & 21.50 & 18 & 125.00 \\
\hline Note N= & & & & \\
\hline
\end{tabular}

Note. $\mathrm{N}=49$ 
Table 2

Pearson Correlations Between the Variables

\begin{tabular}{|c|c|c|c|c|c|c|c|c|c|c|}
\hline Variable & 2 & 3 & 4 & 5 & 6 & 7 & 8 & 9 & 10 & 11 \\
\hline 1. Decision Quality & -.16 & -.04 & .25 & .12 & .21 & .03 & .03 & .25 & $.31^{*}$ & -.20 \\
\hline 2. Gc score & -- & .10 & -.23 & .21 & .03 & .16 & -.16 & .15 & .001 & -.01 \\
\hline 3. Gf score & & -- & .04 & -.003 & .10 & .20 & -.04 & .30 & .14 & .10 \\
\hline 4. WM span & & & -- & -.10 & .13 & -.10 & .10 & .11 & .20 & .10 \\
\hline 5. Selectivity & & & & -- & $.65^{* *}$ & $-.34 *$ & -.06 & $.49 * *$ & $.62 * *$ & -.30 \\
\hline 6. Proportion of Information Searched & & & & & -- & $-.31 *$ & -.30 & $.78^{* *}$ & $.96^{* *}$ & -.10 \\
\hline 7. Feature-based Order - Betty & & & & & & -- & $.30^{*}$ & .10 & $-.31 *$ & -.10 \\
\hline 8. Feature-based Order - Anna & & & & & & & -- & .13 & -.22 & -.20 \\
\hline 9. Total time & & & & & & & & -- & $.81 * *$ & -.02 \\
\hline 10. Pieces of information Searched & & & & & & & & & -- & -.10 \\
\hline 11. Age in years & & & & & & & & & & -- \\
\hline
\end{tabular}


Cognition, Processes, and Decision Outcomes 51

Table 3

Summary of Linear Regression Analyses Predicting Decision Quality $(N=49)$

\begin{tabular}{ccccc}
\hline Variable & $b$ & $S E b$ & $t$ & $\beta$ \\
Gc score & -.11 & .24 & -.47 & -.07 \\
Gf score & -.02 & .14 & -.14 & -.02 \\
WM span & .60 & .41 & 1.47 & .23 \\
\hline
\end{tabular}

Note. Full Model $R$ square $=.067, \mathrm{~ns}$.

$F(3,45)=1.09$, ns. 
Cognition, Processes, and Decision Outcomes 52

Table 4

Summary of Linear Regression Analyses Predicting Decision Quality $(N=48)$

\begin{tabular}{lccc}
\hline \multicolumn{1}{c}{ Variable } & B & SE B & $\beta$ \\
\hline Amount of Information Searched & 5.14 & 2.50 & .32 \\
Feature-based Order - Betty & 1.22 & 1.73 & .11 \\
Feature-based Order - Anna & 1.20 & 2.01 & .10 \\
\hline Note. Full Model $R$ square $=.091$, ns. & & & \\
$F(3,44)=.24$, ns. & & &
\end{tabular}


Table 5

Summary of Hierarchical Regression Analyses Predicting Decision Quality $\underline{(N=49)}$

$\begin{array}{llll}\text { Variable } & \text { B } & \text { SE B } & \beta\end{array}$

Step 1

Amount of Information Searched

2.90

2.20

.20

Step 2

\begin{tabular}{lrrr} 
Amount of Information Searched & 2.50 & 2.20 & .16 \\
WM span & .62 & .40 & .23 \\
\hline
\end{tabular}

Note. $R^{2}=.035$ for Step $1 ; \Delta R^{2}=.053$ for Step 2

Final $R^{2}=.088$

$F(1,47)=.20$, ns. for Step 1

$F(1,46)=.11$, ns. for Step 2 
Cognition, Processes, and Decision Outcomes 54

Table 6

Summary of Exploratory Linear Regression Analyses Predicting Decision Quality $(N=49)$

$\begin{array}{llll}\text { Variable } & \text { B } & \text { SE B } & \beta\end{array}$

\begin{tabular}{llll}
\hline Gender & -.19 & .13 & -.20 \\
Affective Information & & & \\
$\quad$ Betty & $.36^{*}$ & .17 & .30 \\
\hline
\end{tabular}

Note. Full Model $R$ square $=.36, p<.05$.

$F(2,46)=3.40, \mathrm{p}<.05$

$* p<.05$ 
Cognition, Processes, and Decision Outcomes 55

Table 7

Summary of Linear Regression Analyses Predicting Decision Quality $(N=49)$

\begin{tabular}{cccc}
\hline Variable & B & SE B & $\beta$ \\
\hline Amount of Information Searched & -3.00 & 19.30 & -.03 \\
Search Selectivity & 3.12 & 2.80 & .20 \\
\hline
\end{tabular}

Note. Full Model $R$ square $=.04$, ns.

$F(2,46)=.44$, ns. 
Cognition, Processes, and Decision Outcomes 56

Table 8

Pearson Correlations Between the Cognitive and Search Strategy Variables

\begin{tabular}{|c|c|c|c|c|c|c|}
\hline Variable & 2 & 3 & 4 & 5 & 6 & 7 \\
\hline 1. Gc score & .10 & $-.34 *$ & .22 & .03 & .16 & -.16 \\
\hline 2. Gf score & -- & -.002 & -.009 & .10 & .17 & -.04 \\
\hline 3. WM span & & -- & -.12 & .11 & -.10 & .10 \\
\hline 4. Selectivity & & & -- & $.61 * *$ & $-.34 *$ & -.06 \\
\hline 5. Proportion of Information Searched & & & & -- & $-.31^{*}$ & -.27 \\
\hline 6. Feature-based Order - Betty & & & & & -- & $.30^{*}$ \\
\hline 7. Feature-based Order - Anna & & & & & & -- \\
\hline$N=49 * p<.05 * * p<.01$ & & & & & & \\
\hline
\end{tabular}




\section{Appendix A}

\section{Decision Vignettes}

1. Anna is a 65-year-old widow who currently lives along in her third floor apartment in the city. Her 40-year-old daughter visits her twice daily to cook and clean for Anna since her physical health is so poor. Due to diabetes, she is unable to walk and her vision is poor. Anna lives on less than $\$ 600$ a month from Social Security and her husband's pension. Her only visitors are her daughter and son-in-law, even though Anna had once been quite active in community groups. She complains the she misses being with others and that she doesn't want to continue to burden her daughter. Anna is thinking about moving to a new home.

2. Betty is a 70-year-old widow whose six children live out of state. She lives in the suburb of a large city where she has lived for the past 52 years. She has a good income from her husband's pension, Social Security, and her investments. She has a few close friends nearby and is well acquainted with the neighbors. She enjoys the many young families who live near her, but she wants to interact more with people her own age. Her health is very good, with only minor arthritis. In fact, she still drives her own car and does most of her own housework, although the heavy housework is becoming too much for her alone. Betty's children would like her to think about moving to a new home. 


\section{Appendix B}

Anna

\begin{tabular}{|c|c|c|c|c|c|c|c|c|}
\hline & Rent & Size & Locale & $\begin{array}{l}\text { Medical } \\
\text { Services }\end{array}$ & $\begin{array}{l}\text { Non-Medical } \\
\text { Services }\end{array}$ & Social & Safety & Rules/Options \\
\hline 1. & $\begin{array}{l}\text { \$2,775; } \\
\text { utilities; No } \\
\text { Medicaid } \\
\text { or } \\
\text { Medicare }\end{array}$ & $\begin{array}{l}\text { Average; } 1 \\
\text { bedroom; } 1 \\
\text { bath; } 550 \\
\text { sqft. }\end{array}$ & $\begin{array}{l}\text { Good; Near } \\
\text { large } \\
\text { metropolitan } \\
\text { area }\end{array}$ & $\begin{array}{l}\text { Limited; } \\
\text { Registered } \\
\text { nurse during } \\
\text { day; } \\
\text { Personal } \\
\text { Care } \\
\text { Assistants } \\
\text { 24-hr. } \\
\end{array}$ & $\begin{array}{l}\text { Excellent; } \\
\text { laundry, } \\
\text { heavy } \\
\text { housework; } 1 \\
\text { full \& } 2 \text { light } \\
\text { meals }\end{array}$ & $\begin{array}{l}\text { Excellent; } \\
\text { All seniors; } \\
\text { On-site } \\
\text { exercise } \\
\text { room; daily } \\
\text { programs }\end{array}$ & $\begin{array}{l}\text { Excellent; } \\
\text { Reception } \\
\text { desk \& } \\
\text { alarm at } \\
\text { entry; each } \\
\text { unit has } \\
\text { private } \\
\text { system } \\
\end{array}$ & $\begin{array}{l}\text { Visitors can } \\
\text { stay over; } \\
\text { middle sized } \\
\text { cat/dog with } \\
\text { deposit }\end{array}$ \\
\hline 2. & $\begin{array}{l}\$ 930 ; \\
\text { utilities; No } \\
\text { Medicaid or } \\
\text { Medicare }\end{array}$ & $\begin{array}{l}\text { Small; } 1 \\
\text { bedroom, } 1 \\
\text { bath; } 448 \\
\text { sqft. }\end{array}$ & $\begin{array}{l}\text { Excellent; } \\
\text { Near large } \\
\text { city; close to } \\
\text { shopping } \\
\text { and } \\
\text { recreation }\end{array}$ & $\begin{array}{l}\text { Limited; 24- } \\
\text { hr. } \\
\text { emergency } \\
\text { call system; } \\
\text { weekly visit } \\
\text { by RN }\end{array}$ & $\begin{array}{l}\text { Very good; } \\
\text { laundry } \\
\text { facilities, full } \\
\text { dinner, } 2 \text { light } \\
\text { meals }\end{array}$ & $\begin{array}{l}\text { Very good; } \\
\text { All seniors; } \\
\text { daily classes } \\
\& \text { programs }\end{array}$ & $\begin{array}{l}\text { Very good; } \\
\text { security } \\
\text { entrance; } \\
\text { each unit } \\
\text { has double } \\
\text { locks }\end{array}$ & $\begin{array}{l}\text { No pets; daily } \\
\text { visitors, } \\
\text { cannot stay } \\
\text { over }\end{array}$ \\
\hline 3. & $\begin{array}{l}\text { \$600; No } \\
\text { utilities; No } \\
\text { Medicaid or } \\
\text { Medicare }\end{array}$ & $\begin{array}{l}\text { Large; } 2 \\
\text { bedrooms; } 1 \\
\text { and one-half } \\
\text { bath; } 1220 \\
\text { sqft. }\end{array}$ & $\begin{array}{l}\text { Average; } \\
\text { Near } \\
\text { downtown } \\
\text { area; near } \\
\text { business } \\
\text { district, } \\
\text { hospitals }\end{array}$ & $\begin{array}{l}\text { Poor; No } \\
\text { services } \\
\text { offered }\end{array}$ & $\begin{array}{l}\text { Good; Indoor } \\
\text { pool; exercise } \\
\& \text { recreation } \\
\text { rooms; coin } \\
\text { laundry }\end{array}$ & $\begin{array}{l}\text { Poor; No } \\
\text { planned } \\
\text { activities; } \\
\text { mix of age } \\
\text { groups \& } \\
\text { nationalities }\end{array}$ & $\begin{array}{l}\text { Average; } \\
\text { Private, } \\
\text { external key } \\
\text { - lock entry } \\
\text { to units }\end{array}$ & $\begin{array}{l}\text { No pets; } \\
\text { visitors can } \\
\text { stay over }\end{array}$ \\
\hline 4. & $\begin{array}{l}\$ 4,152 ; \\
\text { utilities; } \\
\text { Medicare \& } \\
\text { Medicaid } \\
\text { accepted }\end{array}$ & $\begin{array}{l}\text { Small; } 1 \\
\text { bedroom; } 1 \\
\text { bath; } 300 \\
\text { sqft. }\end{array}$ & $\begin{array}{l}\text { Excellent; } \\
\text { near large } \\
\text { metro area; } \\
\text { landscaped } \\
\text { ground }\end{array}$ & $\begin{array}{l}\text { Excellent; } \\
\text { complete, } \\
24-\text { hr. } \\
\text { physician \& } \\
\text { RN's; acute } \\
\text { care }\end{array}$ & $\begin{array}{l}\text { Excellent; } 3 \\
\text { full meals; } \\
\text { housekeeping, } \\
\text { laundry, } \\
\text { personal care }\end{array}$ & $\begin{array}{l}\text { Very good; } \\
\text { All seniors; } \\
\text { activities } \\
\text { director; } \\
\text { daily } \\
\text { programs }\end{array}$ & $\begin{array}{l}\text { Good; } \\
\text { electronic } \\
\text { key entry to } \\
\text { building }\end{array}$ & $\begin{array}{l}\text { No pets; daily } \\
\text { visitors; } \\
\text { cannot stay }\end{array}$ \\
\hline
\end{tabular}




\begin{tabular}{|c|c|c|c|c|c|c|c|c|}
\hline 5. & $\begin{array}{l}\text { \$2,000; } \\
\text { utilities; } \\
\text { Medicare } \\
\& \\
\text { Medicaid } \\
\text { accepted }\end{array}$ & $\begin{array}{l}\text { Average; } 4 \\
\text { bedroom; } 2 \\
\text { baths; } 950 \\
\text { sqft. }\end{array}$ & $\begin{array}{l}\text { Good; } \\
\text { suburban, } \\
\text { residential } \\
\text { area; near } \\
\text { shopping }\end{array}$ & $\begin{array}{l}\text { Good; Daily } \\
\text { visiting } \\
\text { nurse; } \\
\text { trained } \\
\text { house - } \\
\text { supervisor }\end{array}$ & $\begin{array}{l}\text { Very good; } 3 \\
\text { full meals; } \\
\text { laundry, } \\
\text { housekeeping }\end{array}$ & $\begin{array}{l}\text { Good; all } \\
\text { seniors; } \\
\text { daily } \\
\text { activities \& } \\
\text { weekly trips }\end{array}$ & $\begin{array}{l}\text { Good; key } \\
\text { pad entry; } \\
\text { security } \\
\text { station }\end{array}$ & $\begin{array}{l}\text { Pets with } \\
\text { deposit; } \\
\text { visitors } \\
\text { cannot stay }\end{array}$ \\
\hline 6. & $\begin{array}{l}\text { \$1,200; } \\
\text { utilities; } \\
\text { Medicare \& } \\
\text { Medicaid } \\
\text { accepted }\end{array}$ & $\begin{array}{l}\text { Small; } 1 \\
\text { bedroom; } 1 \\
\text { bath; } 300 \\
\text { sqft. }\end{array}$ & $\begin{array}{l}\text { Average; } \\
\text { near urban } \\
\text { area }\end{array}$ & $\begin{array}{l}\text { Good; } \\
\text { complete, } \\
24-\mathrm{hr} \text {. } \\
\text { physician; } \\
\text { acute care }\end{array}$ & $\begin{array}{l}\text { Good; } 3 \text { full } \\
\text { meals; } \\
\text { housekeeping, } \\
\text { laundry, } \\
\text { personal care }\end{array}$ & $\begin{array}{l}\text { Good; All } \\
\text { seniors; } \\
\text { daily } \\
\text { programs, } \\
\text { crafts }\end{array}$ & $\begin{array}{l}\text { Average; } \\
\text { receptionist } \\
\text { at building } \\
\text { entry }\end{array}$ & $\begin{array}{l}1 \text { pet under } \\
10 \text { lbs. with } \\
\text { deposit; } \\
\text { visitors can } \\
\text { stay }\end{array}$ \\
\hline 7. & $\begin{array}{l}\$ 1,295 ; \\
\text { utilities; No } \\
\text { Medicaid or } \\
\text { Medicare }\end{array}$ & $\begin{array}{l}\text { Large; } 2 \\
\text { bedrooms; } 2 \\
\text { baths; } 2200 \\
\text { sqft. }\end{array}$ & $\begin{array}{l}\text { Excellent; } \\
\text { near } \\
\text { suburban } \\
\text { shopping; } \\
\text { landscaped } \\
\text { grounds }\end{array}$ & $\begin{array}{l}\text { Poor; } \\
\text { emergency } \\
\text { call }\end{array}$ & $\begin{array}{l}\text { Average; coin } \\
\text { laundry; light } \\
\text { breakfast }\end{array}$ & $\begin{array}{l}\text { Average; } \\
\text { Age-mixed } \\
\text { residents; } \\
\text { indoor pool }\end{array}$ & $\begin{array}{l}\text { Very good; } \\
\text { electronic } \\
\text { entry to } \\
\text { building and } \\
\text { units }\end{array}$ & $\begin{array}{l}\text { Pets under } 25 \\
\text { lbs. with } \\
\text { deposit; } \\
\text { visitors } \\
\text { anytime }\end{array}$ \\
\hline 8. & $\begin{array}{l}\$ 400 ; \\
\text { utilities; No } \\
\text { Medicaid or } \\
\text { Medicare }\end{array}$ & $\begin{array}{l}\text { Average; } 1 \\
\text { bedroom; } 1 \\
\text { bath; } 550 \\
\text { sqft. }\end{array}$ & $\begin{array}{l}\text { Good; } \\
\text { suburban } \\
\text { area; on bus } \\
\text { line to } \\
\text { shopping }\end{array}$ & $\begin{array}{l}\text { Poor; no } \\
\text { services } \\
\text { offered }\end{array}$ & $\begin{array}{l}\text { Poor; no } \\
\text { laundry or } \\
\text { recreation } \\
\text { areas }\end{array}$ & $\begin{array}{l}\text { Limited; age } \\
\text { - mixed } \\
\text { residents }\end{array}$ & $\begin{array}{l}\text { Average; } \\
\text { private } \\
\text { entry, } \\
\text { standard } \\
\text { locks }\end{array}$ & $\begin{array}{l}\text { Pets allowed; } \\
\text { no deposit } \\
\text { required; } \\
\text { visitors } \\
\text { cannot stay }\end{array}$ \\
\hline
\end{tabular}




\begin{tabular}{|c|c|c|c|c|c|c|c|c|}
\hline & Rent & Size & Locale & $\begin{array}{l}\text { Medical } \\
\text { Services }\end{array}$ & $\begin{array}{l}\text { Non-Medical } \\
\text { Services }\end{array}$ & Social & Safety & Rules/Options \\
\hline 1. & $\begin{array}{l}\$ 1,505 \text { per } \\
\text { month; } \\
\text { utilities; No } \\
\text { Medicaid or } \\
\text { Medicare }\end{array}$ & $\begin{array}{l}\text { Average; } 2 \\
\text { bedrooms; } 1 \\
\text { bath; } 950 \\
\text { sqft. }\end{array}$ & $\begin{array}{l}\text { Good; Near } \\
\text { large city }\end{array}$ & $\begin{array}{l}\text { Good; Full } \\
\text { - time RN } \\
\& \text { personal } \\
\text { care } \\
\text { assistants }\end{array}$ & $\begin{array}{l}\text { Excellent; } \\
\text { housekeeping } \\
\text { services; } 2 \\
\text { meals; } \\
\text { pharmacy }\end{array}$ & $\begin{array}{l}\text { Excellent; } \\
\text { All seniors; } \\
\text { exercise } \\
\text { room; daily } \\
\text { activities }\end{array}$ & $\begin{array}{l}\text { Excellent; } \\
\text { Reception } \\
\text { desk \& } \\
\text { alarm; } \\
\text { private } \\
\text { alarms }\end{array}$ & $\begin{array}{l}\text { Pets with } \\
\text { deposit; } \\
\text { visitors } \\
\text { cannot stay }\end{array}$ \\
\hline 2. & $\begin{array}{l}\$ 300 \text { per } \\
\text { month; No } \\
\text { utilities } \\
\text { paid; } \\
\text { Medicaid \& } \\
\text { Medicare }\end{array}$ & $\begin{array}{l}\text { Average; } 1 \\
\text { bedroom; } 1 \\
\text { bath; } 900 \\
\text { sqft. }\end{array}$ & $\begin{array}{l}\text { Poor; } \\
\text { Downtown } \\
\text { area; close } \\
\text { to business } \\
\text { district \& } \\
\text { night clubs }\end{array}$ & $\begin{array}{l}\text { Good; } \\
\text { trained } \\
\text { supervisor; } \\
24 \mathrm{hr} \text {. } \\
\text { emergency } \\
\text { call }\end{array}$ & $\begin{array}{l}\text { Average; } \\
\text { party room; } \\
\text { billiards; } \\
\text { laundry }\end{array}$ & $\begin{array}{l}\text { No planned } \\
\text { activities; } \\
\text { adults only, } \\
\text { many with } \\
\text { disabilities }\end{array}$ & $\begin{array}{l}\text { Average; } \\
\text { Reception } \\
\text { desk at } \\
\text { entry; } \\
\text { individual } \\
\text { key - lock } \\
\text { entry }\end{array}$ & $\begin{array}{l}\text { No pets; } \\
\text { visitors } \\
\text { anytime }\end{array}$ \\
\hline 3. & $\begin{array}{l}\$ 1,100 \text { per } \\
\text { month; } \\
\text { utilities, } \\
\text { Medicare \& } \\
\text { Medicaid } \\
\text { accepted }\end{array}$ & $\begin{array}{l}\text { Small; } 1 \\
\text { bedroom; } 1 \\
\text { bath; } 300 \\
\text { sqft. }\end{array}$ & $\begin{array}{l}\text { Average; } \\
\text { secluded } \\
\text { grounds; } 40 \\
\text { miles from } \\
\text { nearest city }\end{array}$ & $\begin{array}{l}\text { Excellent; } \\
24-\text { hr. } \\
\text { physician \& } \\
\text { nurses; } \\
\text { acute care } \\
\text { facilities }\end{array}$ & $\begin{array}{l}\text { Excellent; } 3 \\
\text { meals; } \\
\text { housekeeping } \\
\& \text { personal } \\
\text { care }\end{array}$ & $\begin{array}{l}\text { Very good; } \\
\text { Frail } \\
\text { seniors; Full } \\
\text { - time } \\
\text { therapist; } \\
\text { daily } \\
\text { programs }\end{array}$ & $\begin{array}{l}\text { Good; } \\
\text { electronic } \\
\text { entry to } \\
\text { building; } \\
\text { low security } \\
\text { for } \\
\text { individual } \\
\text { units }\end{array}$ & $\begin{array}{l}\text { No pets; } \\
\text { visiting hours }\end{array}$ \\
\hline 4. & $\begin{array}{l}\$ 975 \text { per } \\
\text { month; } \\
\text { utilities; No } \\
\text { Medicaid or } \\
\text { Medicare }\end{array}$ & $\begin{array}{l}\text { Large; } 1 \\
\text { bedroom, } 1 \\
\text { bath; } 808 \\
\text { sqft. }\end{array}$ & $\begin{array}{l}\text { Excellent; } \\
\text { Near large } \\
\text { suburban } \\
\text { area; close } \\
\text { to shopping; } \\
\text { bus line }\end{array}$ & $\begin{array}{l}\text { Limited; } 24 \\
\text { - hr. } \\
\text { emergency } \\
\text { call system; } \\
\text { weekly } \\
\text { health } \\
\text { screenings }\end{array}$ & $\begin{array}{l}\text { Very good; } \\
\text { in-house coin } \\
\text { laundry; three } \\
\text { light meals }\end{array}$ & $\begin{array}{l}\text { Very good; } \\
\text { All seniors; } \\
\text { daily classes } \\
\& \\
\text { programs; } \\
\text { weekly trips }\end{array}$ & $\begin{array}{l}\text { Very good; } \\
\text { electronic- } \\
\text { key } \\
\text { entrance; } \\
\text { each unit } \\
\text { has double } \\
\text { locks }\end{array}$ & $\begin{array}{l}\text { Pets under } 10 \\
\text { lbs. with } \\
\text { deposit, } \\
\text { visitors can } \\
\text { stay }\end{array}$ \\
\hline
\end{tabular}




\begin{tabular}{|c|c|c|c|c|c|c|c|c|}
\hline 5. & $\begin{array}{l}\$ 800 \text { per } \\
\text { month; } \\
\text { some } \\
\text { utilities; No } \\
\text { Medicare or } \\
\text { Medicaid }\end{array}$ & $\begin{array}{l}\text { Average; } 2 \\
\text { bedrooms; } 1 \\
\text { bath; } 950 \\
\text { sqft. }\end{array}$ & $\begin{array}{l}\text { Good; } \\
\text { suburban - } \\
\text { metro area; } \\
\text { near } \\
\text { shopping \& } \\
\text { recreation }\end{array}$ & $\begin{array}{l}\text { Good; } \\
\text { weekly } \\
\text { health } \\
\text { screens; } 24 \\
\text { hr. } \\
\text { emergency } \\
\text { call }\end{array}$ & $\begin{array}{l}\text { Very good; } 2 \\
\text { light meals } \\
\text { daily; laundry } \\
\& \\
\text { housekeeping }\end{array}$ & $\begin{array}{l}\text { Good; all } \\
\text { seniors; } \\
\text { daily } \\
\text { activities \& } \\
\text { weekly trips }\end{array}$ & $\begin{array}{l}\text { Average; } \\
\text { electronic } \\
\text { entry to } \\
\text { building and } \\
\text { units }\end{array}$ & $\begin{array}{l}2 \text { pets with } \\
\text { deposit, pet } \\
\text { walking area; } \\
\text { visiting hours }\end{array}$ \\
\hline 6. & $\begin{array}{l}\$ 895 \text { per } \\
\text { month; } \\
\text { utilities; No } \\
\text { Medicaid or } \\
\text { Medicare }\end{array}$ & $\begin{array}{l}\text { Large; } 2 \\
\text { bedrooms; } 1 \\
\text { bath; } 1200 \\
\text { sqft. }\end{array}$ & $\begin{array}{l}\text { Excellent; } \\
\text { near } \\
\text { suburban } \\
\text { shopping, } \\
\text { recreation, } \\
\text { \& cultural } \\
\text { events }\end{array}$ & $\begin{array}{l}\text { Poor; no } \\
\text { extra } \\
\text { services }\end{array}$ & $\begin{array}{l}\text { Average; coin } \\
\text { laundry }\end{array}$ & $\begin{array}{l}\text { Average; } \\
\text { age - mixed } \\
\text { residents; } \\
\text { party room, } \\
\text { exercise } \\
\text { room; tennis } \\
\text { courts }\end{array}$ & $\begin{array}{l}\text { Good; } \\
\text { standard } \\
\text { external key } \\
\text { entry to } \\
\text { building and } \\
\text { units }\end{array}$ & $\begin{array}{l}\text { Pet under } 50 \\
\text { lbs. with } \\
\text { deposit, } \\
\text { visitors can } \\
\text { stay over }\end{array}$ \\
\hline 7. & $\begin{array}{l}\text { \$500 per } \\
\text { month; No } \\
\text { utilities; No } \\
\text { Medicaid or } \\
\text { Medicare }\end{array}$ & $\begin{array}{l}\text { Average; } 1 \\
\text { bedroom; } 1 \\
\text { bath; } 550 \\
\text { sqft. }\end{array}$ & $\begin{array}{l}\text { Poor; } \\
\text { urban, } \\
\text { business } \\
\text { area; on } \\
\text { bus line to } \\
\text { shopping }\end{array}$ & $\begin{array}{l}\text { Poor; no } \\
\text { services } \\
\text { offered }\end{array}$ & $\begin{array}{l}\text { Poor; no } \\
\text { laundry or } \\
\text { recreation } \\
\text { areas offered }\end{array}$ & $\begin{array}{l}\text { Limited; } \\
\text { age - mixed } \\
\text { residents }\end{array}$ & $\begin{array}{l}\text { Average; } \\
\text { private } \\
\text { entry with } \\
\text { standard } \\
\text { locks }\end{array}$ & $\begin{array}{l}\text { Small pets } \\
\text { with deposit; } \\
\text { visitors daily }\end{array}$ \\
\hline 8. & $\begin{array}{l}\$ 1,800 \text { per } \\
\text { month; } \\
\text { utilities; } \\
\text { Medicare \& } \\
\text { Medicaid }\end{array}$ & $\begin{array}{l}\text { Small; } 1 \\
\text { bedroom; } 1 \\
\text { bath; } 280 \\
\text { sqft. }\end{array}$ & $\begin{array}{l}\text { Average; } \\
\text { near urban } \\
\text { area }\end{array}$ & $\begin{array}{l}\text { Good; } \\
\text { complete; } \\
\text { on - call } \\
\text { physician \& } \\
24-\text { hr. } \\
\text { RNs }\end{array}$ & $\begin{array}{l}\text { Good; } 3 \text { full } \\
\text { meals; } \\
\text { housekeeping, } \\
\text { laundry, } \\
\text { personal care }\end{array}$ & $\begin{array}{l}\text { Good; all } \\
\text { seniors; } \\
\text { daily } \\
\text { programs, } \\
\text { crafts }\end{array}$ & $\begin{array}{l}\text { Average; } \\
\text { receptionist } \\
\text { at building; } \\
\text { low security } \\
\text { for } \\
\text { individual } \\
\text { units }\end{array}$ & $\begin{array}{l}\text { Small pets } \\
\text { with deposit; } \\
\text { visiting hours }\end{array}$ \\
\hline
\end{tabular}




\section{Appendix C}

Coglab Memory Span

\begin{tabular}{|c|c|c|c|}
\hline \multicolumn{3}{|c|}{ * Memory span demonstration } & $\square \square x$ \\
\hline \multicolumn{4}{|l|}{ Trials to go Instructions } \\
\hline \multirow{4}{*}{ Recall items } & 1 & 2 & 3 \\
\hline & 4 & 5 & 6 \\
\hline & 7 & 8 & 9 \\
\hline & Next trial & & \\
\hline
\end{tabular}




\section{Appendix D}

\section{Cognitive Components, Information Search Processes, and Outcomes in a Decision Making Task}

Purposes of the Study

The purpose of this study is to examine the association among cognitive components, information search strategies, affective components and hypothetical relocation decisions.

Description of Procedures

This study involves a computerized survey format and will take approximately 2 hours for me to complete. I have been told to complete questionnaires about cognitive components and hypothetical relocation decisions. I have also been told that I may see the questionnaire before signing this consent form and that I do not have to answer all of the questions if I decide to participate. Approximately 90 participants are expected to take part in this study.

For more information about this research, I can contact Beth Stafford, at 304-293-2001, or her supervisor, Dr. Julie Patrick at 304293-2001, x31680. For information regarding my rights as a research participant, I man contact the Office of Research Compliance at 304-293-7073.

Risks and Discomforts

I understand that there is no physical health risk associated with my participation in this study.
Confidentiality

I understand that any information about me obtained as a result of my participation in this research will be kept as confidential as legally possible. I understand that my research records and test results, just like hospital records, may be subpoenaed by court order or may be inspected by the study sponsor or federal regulatory authorities (including the FDA if applicable) without my addition consent. In any publications that result from this research, neither my name nor any information from which I might be identified will be published without my consent.

Voluntary Participation

Participation in this study is voluntary. I understand that I am free to withdraw my consent to participate in this study at any time and that such refusal to participate will not affect my future experiences with West Virginia University. Refusal to participate or withdrawal will involve no penalty to me. I have been given the opportunity to ask questions about the research, and I have received answers concerning areas I did not understand. In the event new information becomes available that may affect my willingness to continue to participate in the study, this information will be given to me to I may make an informed decision about my participation. 
Please enter the following into the web

browser:

http://coglab1.wadsworth.com/

CLICK MEMORY SPAN, under the Working Memory options.

Scroll down and enter:

Username: Patrick-

Password: 


\section{Section B}

Making decisions

On this poster, you see a chart of letters and numbers. Each row in the chart represents one object; in this case, each row is a separate candy bar. Each column represents a specific aspect of the candy bar. In this case, we have 3 aspects: Column 1 is price, Column 2 is size, and Column 3 is taste. If you wanted to know how much Bar $Q$ costs, you would open the door that is labeled Q1. If you wanted to know how big Bar $Q$ is, you would open the door that has $Q 2$ on it. It's the same for Bar W.

Computer Practice Trial with Candy Bar: Instead of using your hand to open the Q1 door, you can type in the letter and number that you want. As you can see, there are only a few keys on the keyboard and they match the letters and numbers you see on the screen. Type in Q1. When you are done with door Q1 and you want to see another door, press the long space bar at the bottom of the keyboard. Now you can pick another door. Go ahead and type in a few door codes and read the information.

When you are ready to choose which candy bar you want, you can tell the computer by pressing the "enter" key. It's the big key on the right side of the keyboard. Go ahead and press it: It says, "Which bar do you choose?". Type your answer, either Q or W.

\section{Suit Decision-- Practice}

Now we're going to try another example. If you have a question, go ahead and ask; we want you to feel comfortable before we start looking at school information. In this example, you will look at information about 4 suits of clothing. A female lawyer needs to buy a suit for work. She has only 4 options, Suit Q, W, E, and R. Each suit is a different color, fabric, price, and style.

Please look through the information and choose the one suit you think she should buy. Remember, each row on the computer is ONE suit; you can't mix and match with different rows. Please begin. Choose the suit for the female lawyer.

\section{Housing Decision for SELF}

Now I am going to show you some information about six different housing options. Each option has information about its price per month, it's size, where it's located, what kinds of housekeeping services are available, different medical services that are available, the type of transportation services available, social opportunities, and security measures. Please look through as much or as little information as you want and choose the one housing option that you would like for yourself. Are you ready to begin? When you are ready, press the space bar, and you will see the information doors for the six housing options.

1a. How satisfied are you with the choice you just made? Would you say:
a. Very satisfied
b. Somewhat satisfied
c. Neutral
d. Somewhat dissatisfied, or
e. Not satisfied at all?

1b. If you were actually going to move to a new home, how likely do you think you would be to move to the kind of home you just chose on the computer? Would you say:
a. Very likely
b. Somewhat likely, or
c. Not likely at all?

\section{Please do not turn the page until asked to do so.}


Now, you will see information about different homes, and I'd like you to look through as much or as little information as you need. Instead of choosing a home for yourself, I'd like you to suggest a home for another person.. When you are ready, press the space bar, and you will see the information doors for the six housing options.

\section{If ID is ODD, Scenario A:}

Anna /Adam is a 65 year old widow(er) who currently lives alone in her/his third floor apartment in the city. Her/his 40 year old daughter visits twice daily to cook and clean for Anna/Adam, since Anna's/Adam's physical health is so poor. Due to diabetes, she/he is unable to walk and her/his vision is poor. Anna/Adam lives on less than $\$ 600$ a month from Social Security and her husband's/his pension. Her/his only visitors are her/his daughter and son-in-law, even though Anna/Adam had once been quite active in many community groups. She/he complains that she/he misses being with others and that she/he doesn't want to continue to burden her/his daughter. Anna/Adam is thinking about moving to a new home.

Anna1. How satisfied are you with the choice you just made? Would you say:

f. Very satisfied

g. Somewhat satisfied

h. Neutral

i. Somewhat dissatisfied, or

j. Not satisfied at all?

\section{If ID is EVEN, Scenario B:}

Betty is a 70-year-old widow whose six children live out of state. She lives in the suburb of a large city where she has lived for the past 52 years. She has a good income from her husband's pension, Social Security, and her investments. She has a few close friends nearby and is well acquainted with the neighbors. She enjoys the many young families who live near her, but she wants to interact more with people her own age. Her health is very good, with only minor arthritis. In fact, she still drives her own car and does most of her own housework, although the heavy housework is becoming too much for her alone. Betty's children would like her to think about moving to a new home.

Betty1. How satisfied are you with the choice you just made? Would you say:

k. Very satisfied

1. Somewhat satisfied

m. Neutral

n. Somewhat dissatisfied, or

o. Not satisfied at all? 


\section{Section E: Background Information about YOU. Please circle your answer.}

1. What is your date of birth? (Month/Day/Year)

2. What is your marital status, are you:

3. What is your religion, are you:
1.) Protestant,
2.) Catholic,
3.) Jewish,
4.) Other, or (Please specify)
5.) None?

4. Do you currently live:
1.) Alone
2.) With a spouse
3.) With a friend/non-relative
4.) With relatives, or (Please specify)
5.) Other? (Please specify)

5. How long have you lived in West Virginia? no. of years

6. To which racial group do you belong:
1.) African American/Black,
2.) Caucasian/ White, or
3.) Other? (Please specify)

7. Are you:
1) Male, or
2) Female?

8. What kind of work have you done most of your life?

9. For what kind of business, company, or agency is that?

10. What is your primary work status? Are you:
1) Employed (full or part-time)
2) Student
3) Retired
4) Unemployed
5) Homemaker
6) Other (Specify)

11. What is the highest grade or level of education you've completed?

12. How much difficulty do you have paying your bills? Would you say: 

1) A great deal of difficulty
2) Some difficulty
3) A little difficulty, or
4) No difficulty?

13. Please circle the letter that describes your total income last year that you (\& household members) received from all sources. Be sure to include Social Security, pensions, bank interest, reparations, annuities, and so forth:

\begin{tabular}{|ll|ll|}
\hline A. & Under $\$ 10,000$ & I. & $\$ 45,000$ to $\$ 49,999$ \\
B. & $\$ 10,000$ to $\$ 14,999$ & J. & $\$ 50,000$ to $\$ 54,999$ \\
C. & $\$ 15,000$ to $\$ 19,999$ & K & $\$ 55,000$ to $\$ 59,999$ \\
D. & $\$ 20,000$ to $\$ 24,999$ & L. & $\$ 60,000$ to $\$ 64,999$ \\
E. & $\$ 25,000$ to $\$ 29,999$ & M. & $\$ 65,000$ to $\$ 69,999$ \\
F. & $\$ 30,000$ to $\$ 34,999$ & N. & $\$ 70,000$ to $\$ 74,999$ \\
G. & $\$ 35,000$ to $\$ 39,999$ & O. & $\$ 75,000$ and over \\
H. & $\$ 40,000$ to $\$ 44,999$ & P. & I do not know/ do not wish to answer \\
\hline
\end{tabular}

14. Are you currently considering moving to a new residence?
1) YES
2) $\mathrm{NO}$

15. How would you rate your overall health at the present time:
1) Excellent
2) Good
3) Fair, or
4) Poor?

16. Is your health now better, about the same, or not as good as it was 3 years ago?
1) Better
2) Same
3) Not as good

17. Do your health problems stand in the way of your doing the things you want to do?
1) Not at all
2) A little
3) A great deal

18. Compared with most other people your age, would you say your health is: 

1) Better,
2) The Same, or
3) Not as good?

19. How would you describe your memory, that is, the ability to remember information you want to remember? Is it:
1.) Excellent,
2.) Good,
3.) Fair, or
4.) Poor?

20.Compared with most people your age, would you say your memory is:

1.) Better,

2.) The Same, or

3.) Not as good?

21. For the following, please check any of the conditions that you now experience and the extent that each condition causes you problems:

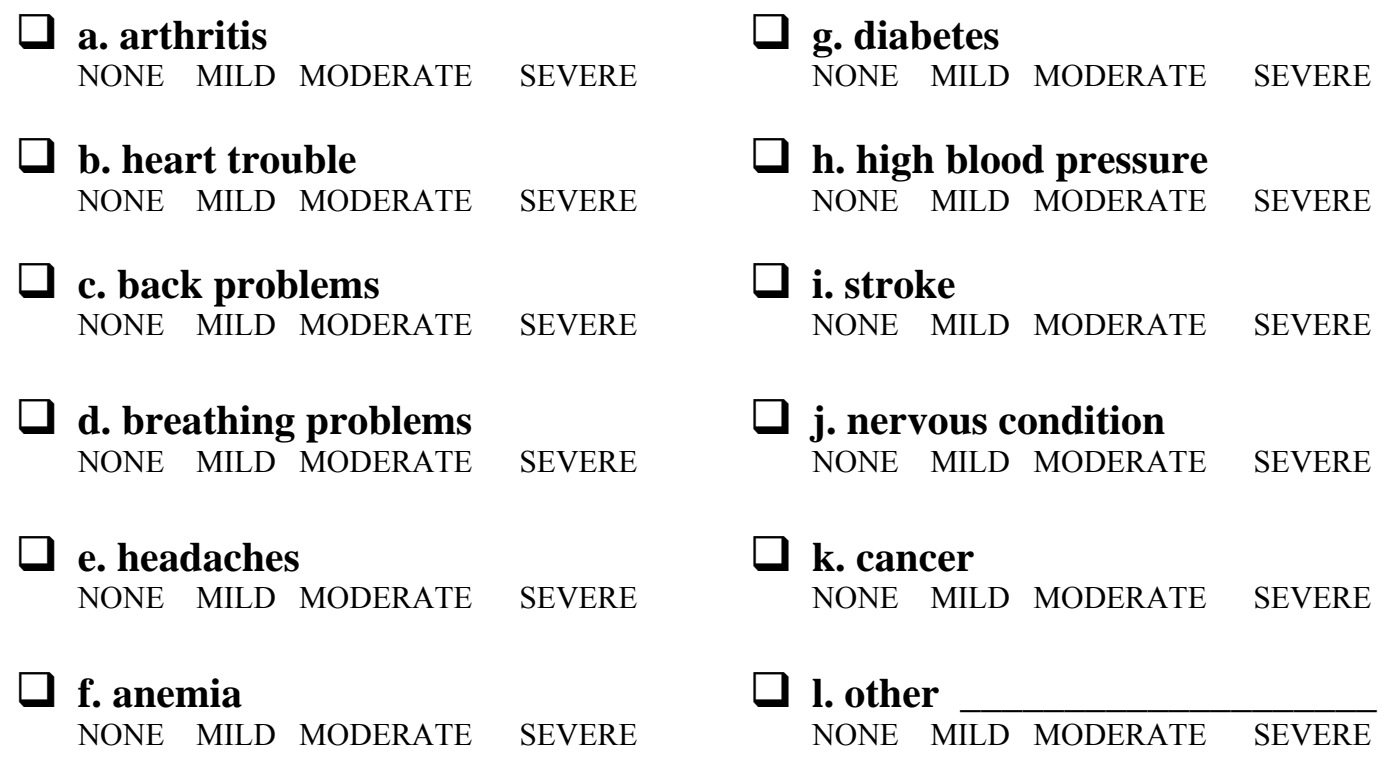

\section{Thank you. Please be sure to complete and submit the honorarium form.}




\section{Appendix E}

\section{Consent and Information Form}

\section{Cognitive Components, Information Search Processes and Outcomes in a Decision Making Task}

Introduction: I, , have been asked to participate in this research study, which has been explained to me by Beth Stafford or her research assistant. This research is being conducted by Beth Stafford and Julie Patrick, Ph.D. to fulfill the requirements for a master's thesis in developmental psychology in the Department of Psychology at West Virginia University, under the supervision of Julie Patrick, Ph.D.

Purposes of the Study: The purpose of the study is to learn more about how people use and combine information to make relocation decisions.

Description of Procedures: This study involves reading information about a variety of housing environments in order to decide which one is superior to the others. This information is presented on a computer screen, and will include information about senior housing environments. In addition, I will be asked to complete several computerized surveys. I may complete these procedures in a community setting (e.g., library), or in the Department of Psychology at WVU, as agreed with the researcher. It will take approximately 1 hour to complete the computerized tasks. Approximately 45 younger adults will be entered into the study. I have been told that I may see the questionnaire before signing this consent and that I do not have to answer all the questions if I decide to participate.

Risks and Discomforts: There are no known or expected risks from participating in this study, except for mild frustration related to the use of a computer.

Alternatives: I understand that I do not have to participate in this study.

Benefits: I understand that this study is not expected to be of direct benefit to me, but the knowledge gained may be of benefit to others. I may receive extra credit in my psychology class, but there are other ways I may earn extra credit.

Contact Persons: For more information about this research, I can contact Beth Stafford, at 304293-2001, or her supervisor, Dr. Julie Patrick at 304-293-2001, x31680. For questions about my rights as a research participant, I can contact the Executive Secretary of the Institutional Review Board at 304- 293-7073.

Version Date: September 2006

Initials

Date

Page 1 of 2 


\section{Cognitive Components, Information Search Processes and Outcomes in a Decision Making Task}

Confidentiality: I understand that any information about me obtained as a result of my participation in this research will be kept as confidential as legally possible. I understand also that my research records, just like hospital records, may be subpoenaed by court order or may be inspected by federal regulatory authorities. In any publications that result from this research, neither my name nor any information from which I might be identified will be published without my consent.

Voluntary Participation: Participation in this study is voluntary. I understand that I am free to withdraw my consent to participate in this study at any time and that such refusal to participate will not affect my class standing or grades. Refusal to participate or withdrawal will involve no penalty to me. I have been given the opportunity to ask questions about the research, and I have received answers concerning areas I did not understand. In the event new information becomes available that may affect my willingness to continue to participate in the study, this information will be given to me so I may make an informed decision about my participation.

Upon signing this form, I will receive a copy.

I willingly consent to participate in this research.

The participant has had the opportunity to have questions addressed. The participant willingly agrees to be in the study.

Signature of Participant

Date

Time

Signature of Investigator or

Date

Time

Investigator's Representative

Version Date: September 2006

Page 2 of 2 